\title{
18. PARAMETERS CONTROLLING ACOUSTIC PROPERTIES OF CARBONATE AND VOLCANICLASTIC SEDIMENTS AT SITES 866 AND 869
}

\author{
Jeroen A.M. Kenter ${ }^{2}$ and Michael Ivanov ${ }^{3}$
}

\begin{abstract}
Comparison of the acoustic and index properties with the petrographic character of 125 brine-saturated carbonate and volcaniclastic rocks from Sites 866 and 869 indicates that porosity is the dominant parameter influencing $P$-and $S$-wave velocity and acoustic impedance. Porosity in the mid-Cretaceous platform carbonates (Site 866) is controlled by diagenetic alteration, rather than primary depositional texture. Replacement and cementation by dolomite yields the highest acoustic velocities. Similarly, porosity in the volcaniclastics (Site 869) is controlled by diagenetic alteration of components and partial replacement and cementing by zeolite.

The density-velocity relationship of the carbonates shows excellent correlation with Gardner's curve for limestone. The general Gardner's curve, however, underestimates the velocities of the volcaniclastics. Laboratory porosity-velocity trends of the carbonates are consistently $5 \%$ to $20 \%$ higher than those predicted by the time-average equation using the correct matrix velocities. Similar crossplots for the volcaniclastics show a division into two distinct subgroups, each corresponding to a time-average equation with a different matrix velocity, which suggests that progressive diagenetic alteration of the volcaniclastics has decreased the matrix velocity. The $V_{p} / V_{s}$ ratios of the carbonates do not discriminate mineralogic composition. Laboratory measurements, under effective pressure simulating in situ conditions, are $5 \%$ to $25 \%$ higher than analyses of velocity made aboard JOIDES Resolution under atmospheric pressure.

The carbonates at Site 866 have a considerably wider range of acoustic impedance than the basalt. As a consequence, the contact between the carbonate succession and the underlying basalt basement in many drowned Cretaceous guyots of the equatorial Pacific Ocean may be difficult to image seismic-reflection profiles.
\end{abstract}

\section{INTRODUCTION}

The complex relationship between acoustic properties and the texture, composition, and facies of sedimentary rocks strongly influences the geological interpretation of wireline logs and seismic reflection data and the seismic modeling of outcrops. To connect seismic data with geology, identifying and quantifying the factors influencing the density and acoustic velocity of the sediments that generate seismicreflection patterns, is essential. Siliciclastics traditionally have been the primary target for research on the acoustic properties of sedimentary rocks, grounded on the fundamental importance of seismic-reflection surveys and well-logging to petroleum exploration. Extensive work over the last few decades has resulted in some conceptual models on the petrophysical classification of siliciclastics (e.g., Wyllie et al., 1958; Birch, 1960, 1961; King, 1966; Gardner et al., 1974; Toksöz et al., 1976; Klimentos and McCann, 1990; Vernik and Nur, 1992). In contrast, little information on the acoustic properties of carbonates is present in the literature. Though several case studies have been published (e.g., Spain, 1983; Rafavich et al., 1984; Wilkens et al., 1984; Biddle et al., 1992; King et al., 1992; Anselmetti and Eberli, 1994), the relationship between sedimentary and petrophysical properties in carbonate rocks is still poorly documented (e.g., see Bourbié et al., 1987).

Complex theoretical models have been proposed for describing the wave propagation in porous media (Gassman, 1951; Kuster and Toksöz, 1974; Winkler, 1983), but a theory accounting for the variety of experimental data does not exist. Experimental studies in siliciclastics, however, suggest that relatively simple relationships exist between seismic velocities and variables such as porosity and clay content (Wyllie et al., 1958; Tosaya and Nur, 1982; Klimentos and

\footnotetext{
${ }^{1}$ Winterer, E.L., Sager, W.W., Firth, J.V., and Sinton, J.M. (Eds.), 1995. Proc. ODP, Sci. Results, 143: College Station, TX (Ocean Drilling Program).

2 Department of Earth Sciences, Vrije Universiteit, De Boelelaan 1085, $1081 \mathrm{HV}$ Amsterdam, The Netherlands.

${ }^{3}$ Geological Department, Moscow State University, Leninskic Gory MGU, Moscow 117234, Russia.
}

McCann, 1990) or bulk density (Nafe and Drake, 1963; Gardner et al., 1974). Vernik and Nur (1992) developed an integrated approach of combined petrophysical and petrographical analysis of siliciclastics that resulted in a new model describing the acoustic behavior of these sediments.

Comparable experimental studies of carbonates have produced no equivalent model for the acoustic behavior of carbonates (Rafavich et al., 1984; King et al., 1992; Anselmetti and Eberli, 1994). The analyzed data sets show different behavior with regard to the timeaverage equation, an empirical velocity-porosity relationship (Wyllie et al., 1958), Gardner's curve, an empirical velocity-density relationship (Gardner et al., 1974), and the $V_{p} / V_{s}$ velocity ratio, which highlights differences in lithology and pore type (Tatham, 1982; Rafavich et al., 1984; Wilkens et al., 1984).

Another uncertainty in the analysis of acoustic properties is relating measurements from small scale to large. Measurements of acoustic velocity on core plugs are at a scale of centimeters and use ultrasonic frequencies (about 0.5 to $1 \mathrm{MHz}$ ), whereas sonic logs average velocity over distances of meters and are measured with lower frequencies (about $10 \mathrm{kHz}$ ), whereas seismic data are at a scale of tens of meters with low frequencies (about $50 \mathrm{~Hz}$ ). Case studies that directly compare cross-hole seismic data and sonic velocity from wireline logs with discrete measurements of acoustic properties are very successful (e.g., Sams et al., 1993), but larger data sets are needed to expand the correlation to the wider range of lithologic types and acoustic properties.

Over the years, standard Ocean Drilling Program procedure was to measure acoustic properties of the recovered lithified sediments on 1-in.-diameter cubes under atmospheric pressure on a HamiltonFrame velocimeter. Little information is available in the literature on the correlation between these measurements and analyses of cylindrical rock specimens under effective pressure and brine-saturated conditions. To use the vast ODP data set available, it is important to establish a correlation between the two methods.

In this study, we present combined petrophysical (bulk density, grain density, porosity, and acoustic velocity under effective pressure simulating in-situ conditions) and petrographic analyses of 1251 -in.- 
diameter minicores from Sites 866 and 869 , and correlate the results with existing empirical equations of Gardner et al. (1974) and Wyllie et al. (1958). The velocity measurements are compared with shipboard measurements from the 1-in. cubes and minicores under atmospheric pressure and the log velocity.

\section{GENERAL LITHOLOGY AT SITES 866 AND 869}

Sites 866 and 869 penetrate sedimentary rocks of two completely different depositional origins and mineralogic compositions. Site 866 is located $1.5 \mathrm{~km}$ behind the margin of Resolution Guyot and drilled a thin pelagic cap, $1620 \mathrm{~m}$ of Barremian-Albian shallow-water, mainly lagoonal, carbonates, and $125 \mathrm{~m}$ of subaerial basalt flows. The recovered carbonates have low clay-content (less than 5\%) and exhibit variable degrees of dolomitization. Measurement on samples from Sites $867 / 868$, drilled nearby, were added to the Site 866 data set, but constitute only a small fraction of the whole data set. Hole $867 \mathrm{~B}$ was drilled in the carbonate platform margin, whereas Hole $868 \mathrm{~A}$ penetrated the seaward side of the margin. Samples from all three holes are combined because they reflect the acoustic properties of the entire margin of Resolution Guyot.

Site 869 was drilled in the distal sediment apron flanking Wodejebato Guyot and Pikinni (formerly Bikini Atoll). The sedimentary section consists of $208 \mathrm{~m}$ of alternating nannofossil ooze, radiolarian nannofossil ooze, clayey nannofossil ooze, and chert of early Miocene to early Maastrichtian age, which overlie $589 \mathrm{~m}$ of volcaniclastic sandstone to breccia, graded and laminated, interbedded with calcareous claystones. Figure 1 shows simplified lithologic columns along with smoothed versions of the sonic velocity and neutron density for both Sites 866 (Fig. 1A) and 869 (Fig. 1B). In addition, discrete measurements of acoustic properties and density and calculated acoustic impedance are shown with the wireline logs. Processed logs were smoothed by applying a 5 -point $(0.61 \mathrm{~m})$ moving average and resampled to a $6-\mathrm{m}$ interval by averaging data over $\pm 3 \mathrm{~m}$.

\section{METHODS \\ Petrography}

For each sample of the core analyzed for acoustic properties, a thin section was prepared from one of the end pieces of the cylindrical 1-in.-diameter minicores that were drilled aboard JOIDES Resolution. The thin sections were impregnated with blue epoxy to identify porosity and stained to determine the mineralogy. Because most of the samples are nearly pure carbonate, grain density was used as a proxy for mineralogy (Zenger, 1968). The samples from Site 866 are nearly pure carbonates varying in mineralogy from $100 \%$ calcite to $100 \%$ dolomite. The percentage of dolomite in the Site 866 samples is calculated using,

$$
\text { Dolomite }(\%)=\left[\left(\rho_{c}-\rho_{\text {calcite }}\right) / 0.148\right) \cdot 100,
$$

where $\rho_{c}$ is the grain density corrected to values between 2.718 and $2.866 \mathrm{~g} / \mathrm{cm}^{3}$, grain densities for calcite and dolomite, respectively (Carmichael, 1989).

Primary depositional textures of the Site 866 samples range from a well-sorted oolitic and peloidal grainstone to rudstone, fossiliferous wackestone and mudstone, and some completely dolomitized textures. Dominant porosity types are interparticle, moldic, microcrystalline, and intercrystalline and intracrystalline porosities. Specimens from Site 866 were discriminated by primary depositional texture (carbonate classification according to Dunham, 1968), mineralogy, and type of porosity. A fourth variable analyzed is the presence and character of cement.

The volcaniclastic sediments from Site 869 have been subdivided according to depositional texture (siltstone and sandstone, breccia, and basalt), grain preservation (altered vs. unaltered), type of porosity (interparticle and intercrystalline), and the presence of zeolite to re- place volcanic components and/or to fill pores. Specimens that have volcanic components (basalt and glass fragments) with abundant and extensive reaction rims, have been labelled "altered." In contrast, specimens of volcanic components with minor, or absent, reaction rims are categorized as "unaltered." Table 1 summarizes the petrographic categories of the rock specimens from both Sites 866 and 869 .

\section{Acoustic Properties}

Procedures for the sampling and measurement of acoustic velocity and density of the 1-in. cubes and 1-in. minicores aboard ship have been described in the Initial Reports volume of Leg 143 (Sager, Winterer, Firth, et al., 1993). $P$-wave velocity was measured in both longitudinal and transverse directions ( $V_{p l}$ and $V_{p t}$, respectively) in both cubes and minicores, some of which were cut from adjacent samples. Shipboard measurements from Sites 866 and 869 are listed in the Initial Reports volume (Sager, Winterer, Firth, et al., 1993). Those acoustic velocity measurements included only $P$-wave velocity and were performed under drained conditions and at atmospheric pressure.

Nearly 125 minicores were collected during Leg 143 from cores from Sites 866 and 869 . After the $P$-wave velocity was measured on the Hamilton-Frame velocimeter, the samples were stored in sample containers and sealed to prevent evaporation and drying of the rock specimens. Upon arrival at the Vrije Universiteit laboratory, all of the specimens were resaturated with seawater ( $35 \% \circ \mathrm{NaCl}$-solution) under vacuum for $48 \mathrm{hr}$.

$P$-wave and $S$-wave velocities were measured in the petrophysics laboratory of the Royal School of Mines, Imperial College, London. The samples were trimmed to approximately 0.75 to 1.5 in. (1.9-3.8 $\mathrm{cm}$ ) long, and the sample ends were ground flat and parallel to within 0.001 in. Each specimen was assembled between the brass end pieces within the nitrile rubber jacket of a Hoek triaxial test cell. Lead foil disks were placed between each end piece and the rock specimen to provide the acoustic coupling necessary for the $S$-wave measurements.

The cell is designed for a maximum confining pressure on the specimen of $100 \mathrm{MPa}$ (about 15.000 psi or $1000 \mathrm{bar}$ ). Ports in the upper brass end piece permit pore-fluid drainage from the specimen when under stress. The $P$ - and $S$-wave transducers are each switched sequentially to produce and to detect pulses of either type of wave. The pulse train bandwidths are as follows: $P$-wave, 500 to $900 \mathrm{kHz} ; S$-wave, 300 to $700 \mathrm{kHz}$. The time-of-flight method, as described by Tao and King (1990), was used to determine the $P$ - and $S$-wave velocities. A hydrostatic stress of $1 \mathrm{MPa}$ was first applied with the hydraulic pressure system to allow the lead foil disks to bed down and to permit unequivocal picks for $S$-wave arrivals. We applied effective pressures, ranging from 5 to $40 \mathrm{MPa}$, to simulate in-situ stress conditions. The precision of the $P$ - and $S$-wave velocities, in consideration of the combined effect of inaccurate readings of the first arrivals and the consolidation of highly porous samples, is limited to within approximately 5\%. A total of 124 specimens was measured for $P$ - and $S$-wave velocities in longitudinal $\left(V_{p l}\right.$ and $\left.V_{s l}\right)$ and transverse $\left(V_{p t}\right.$ and $\left.V_{s t}\right)$ directions (see Tables 2 and 3 ). The temperature during measurements varied between $18^{\circ}$ and $20^{\circ} \mathrm{C}$. The effect of the slightly elevated temperature during laboratory measurement of the acoustic properties was assumed to be minimal, probably less than 1\% (Bourbié et al., 1987; Carmichael, 1989).

\section{Index Properties}

Measurements of the index properties, bulk density, grain density, and porosity were performed at the petrophysics laboratory at the Vrije Universiteit. The individual sample volume $\left(V_{b c}\right)$ was determined by direct measurement using calipers. As the diameter can vary along the sample, an average of several readings accurate to within \pm 0.001 in. $(0.025 \mathrm{~mm})$ was used to determine the diameter. Samples that were damaged or otherwise imperfect cylinders were rejected. Dry-sample masses were measured to within $0.001 \mathrm{~g}$ after the sam- 
Table 1. Dominant petrographic groups of rock specimens from Sites 866 and 869.

\begin{tabular}{|c|c|c|c|c|c|}
\hline \multicolumn{6}{|c|}{ Carbonate specimens } \\
\hline Code & Fabric & Mineralogy & Original fabric & Porosity & Observations \\
\hline $1 \mathrm{a}$ & Grainstone & Calcite & - & BG & Less than $75 \%$ \\
\hline $1 \mathrm{~b}$ & Grainstone & $100 \%$ calcite & - & Occluded & Calcite cement $<30 \%$ of pore space \\
\hline 2 & Packstone & $100 \%$ calcite & - & MP & - \\
\hline 3 & Wackestone & $100 \%$ calcite & - & MP & - \\
\hline 4 & Mudstone & $100 \%$ calcite & - & MP & 一 \\
\hline $5 \mathrm{a}$ & Dolomite & Calcite-dolomite & Grainstone & $\mathrm{MP}$ and $\mathrm{BC}$ & Dolomite \\
\hline $5 \mathrm{~b}$ & Dolomite & (Calcite) dolomite & Grainstone & $\mathrm{BC}$ & - \\
\hline $5 c$ & Dolomite & Dolomite & Unknown & $\mathrm{BC}$ & - \\
\hline $6 a$ & Rudstone & Calcite (dolomite) & - & BG & Dolomite replacement \\
\hline $6 \mathrm{~b}$ & Rudstone & Calcite & - & MOP & $100 \%$ of BG filled by cement or micrite \\
\hline $6 \mathrm{c}$ & Rudstone & Calcite & 一 & Nihil & $100 \%$ of BG filled by cement or micrite \\
\hline \multicolumn{6}{|c|}{ Volcanic-volcaniclastic specimens } \\
\hline & Fabric & Grain character & Porosity & & Observations \\
\hline 7 & Basalt & Nonaltered & BC & - & \\
\hline 8 & Siltstone & Altered grains & $\mathrm{BG}, \mathrm{BC}$ & Minor zeolite & cement \\
\hline $9 \mathrm{a}$ & Sandstone & Altered grains & $\mathrm{BG}, \mathrm{BC}$ & Minor zeolite & cement \\
\hline $9 \mathrm{~b}$ & Sandstone & Nonaltered grains & $\mathrm{BC}$ & Zeolite cemer & nt filling pores and replacing other minerals \\
\hline $10 \mathrm{a}$ & Breccia & Altered grains & BG, BC & Minor zeolite & \\
\hline $10 \mathrm{~b}$ & Breccia & Nonaltered grains & $\mathrm{BC}$ & Zeolite cemer & nt filling pores and replacing other minerals \\
\hline
\end{tabular}

Notes: Code $=$ petrographic group as referred to in text. $\mathrm{BG}=$ between grains; $\mathrm{MP}=$ microcrystalline porosity; $\mathrm{BC}=$ between crystals; $\mathrm{MOP}=$ moldic porosity. See text for explanation.

ples were oven-dried at $70^{\circ} \mathrm{C}$ for $48 \mathrm{hr}$. Dry bulk densities $\left(\rho_{d}\right)$ were corrected for salt content and have been calculated using the formula,

$$
\rho_{d}=\left(W_{g}^{\prime}-W_{s}\right) / V_{b c}
$$

where $W_{\mathrm{g}}{ }^{\prime}$ is the weight of the dry sample and $W_{s}$ is the weight of the salt, which was calculated using the formula,

$$
W_{s}=\left(W_{b w}-W_{g}{ }^{\prime}\right) \cdot 0.024,
$$

where $W_{b w}$ is the wet-bulk weight of the sample. Bulk density $\left(\rho_{b}\right)$ was calculated from

$$
\rho_{b=}\left(W_{g}^{\prime}+V_{p} \cdot \rho_{s w}\right) / V_{b c},
$$

where $\rho_{s w}$ is the density of seawater $\left(1.024 \mathrm{~g} / \mathrm{cm}^{3}\right)$, and $V_{p}$ is the total volume of the pores. Part of the sample was crushed and used to determine the grain density using the formula,

$$
\rho_{g}=W_{g} / V_{g},
$$

where $W_{g}$ is the weight of the grains after drying for $48 \mathrm{hr}$ at $70^{\circ} \mathrm{C}$ and $V_{g}$ is the grain volume measured using a Micrometrics AccuPyc 3200 helium pycnometer. Total porosity $\left(n_{t}\right)$ was then calculated using,

$$
n_{t}=\left(1-\rho_{d} / \rho_{g}\right) \cdot 100 .
$$

Grain density determined in this manner has an accuracy of \pm 0.02 $\mathrm{g} / \mathrm{cm}^{3}$; bulk density has an accuracy of $\pm 0.5 \mathrm{~g} / \mathrm{cm}^{3}$; and porosity has an accuracy of $\pm 3 \%$. Temperature during the analyses varied between $21^{\circ}$ and $25^{\circ} \mathrm{C}$. Table 2 summarizes the measured index properties for rock specimens from both Sites 866 and 869 .

\section{Data Set}

Figure 2 shows histograms for bulk density, total porosity, longitudinal compressional velocity $\left(V_{p l}\right)$, and impedance for sediments from Sites 866 and 869 . Bulk density in the carbonate sediments (including the basalt specimens at the bottom of Hole 866A) ranges from 2.16 to $2.86 \mathrm{~g} / \mathrm{cm}^{3}$, porosity ranges from $1.3 \%$ to $31.3 \%$, and grain density ranges from 2.60 to $2.92 \mathrm{~g} / \mathrm{cm}^{3}$. In the volcaniclastic sediments, bulk density varies between 1.97 and $2.42 \mathrm{~g} / \mathrm{cm}^{3}$, porosity varies between $11.7 \%$ and $55.9 \%$, and grain density ranges from 2.25 to $2.81 \mathrm{~g} / \mathrm{cm}^{3} . V_{p l}$ in the carbonate specimens ranges from 3.16 to 6.94 $\mathrm{km} / \mathrm{s}$; in the volcaniclastic sediments, $V_{p l}$ varies between 2.33 and
$4.81 \mathrm{~km} / \mathrm{s}$. Acoustic impedance values of the sediments from Site 866 range from $6.8 \times 10^{6}$ to $18.4 \times 10^{6} \mathrm{~kg} / \mathrm{m}^{2} / \mathrm{s}$, whereas in the sediments from Site 869 , impedance varies between 4.9 and $11.4 \times 10^{6} \mathrm{~kg} / \mathrm{m}^{2} / \mathrm{s}$.

\section{RESULTS}

\section{Laboratory vs. Shipboard Measurements and Logging Velocity}

Crossplots of $P$-wave velocity measured in cubes vs. minicores exhibit no significant difference. In-situ measurements on the carbonate specimens from Site 866 clearly have velocities, both vertical and horizontal, that are about $10 \%$ to $25 \%$ higher than those measured under atmospheric conditions (Fig. 3A). Crossplots of the Site 869 specimens show a similar trend, but here, in-situ measurements exhibit velocities only $5 \%$ to $10 \%$ higher than those measured under atmospheric conditions (Fig. 3B).

Figure 4 shows the comparison between $\log$ velocity and $V_{p l}$ measured in minicores under confining pressure. Sonic logs from both Sites 866 and 869 were smoothed by applying a 5-point $(0.61 \mathrm{~m}$ or $2 \mathrm{ft}$ ) moving average window (see also Fig. 1). As recovery was relatively low at both sites, sonic velocity was selected by hand from the logs over the entire core interval. Figure 4A shows a crossplot of logging velocity and velocity from minicores from Site 866 specimens. Discrete velocity is close to the logging velocity in the range of up to $5 \mathrm{~km} / \mathrm{s}$, whereas discrete velocities over $5 \mathrm{~km} / \mathrm{s}$ tend to be higher than the logging velocity. A similar plot for the Site 869 specimens shows no clear difference between discrete and logging velocities (Fig. 4B). Note that the comparison is obscured by low recovery, which caused core-log depth offsets and lithologic variation.

\section{$V_{p l}$ vs. Density and Porosity (Undiscriminated Data Sets)}

Two equations that are commonly used by exploration geophysicists to relate physical properties and lithology are the empirical equation by Nafe and Drake (1963) and that of Gardner et al. (1974). The general Gardner's equation is,

$$
\rho=1.741 \cdot V_{p}^{0.25},
$$

where $\rho$ is density in $\mathrm{g} / \mathrm{cm}^{3}$ and $V_{p}$ is velocity in $\mathrm{km} / \mathrm{s}$; this expression relates velocity with density, and is an empirical average for all 
A
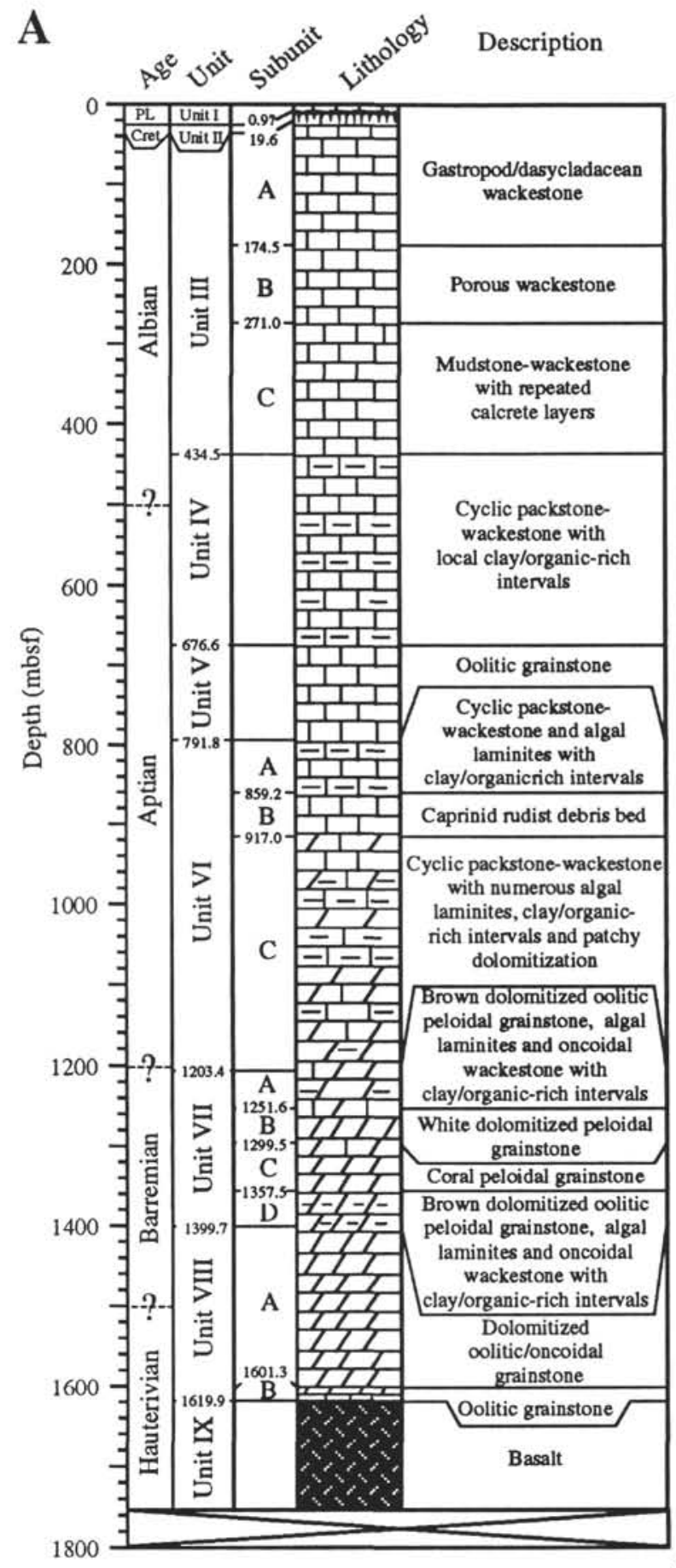

Bulk density $\left(\mathrm{g} / \mathrm{cm}^{3}\right)$

Velocity $(\mathrm{km} / \mathrm{s})$
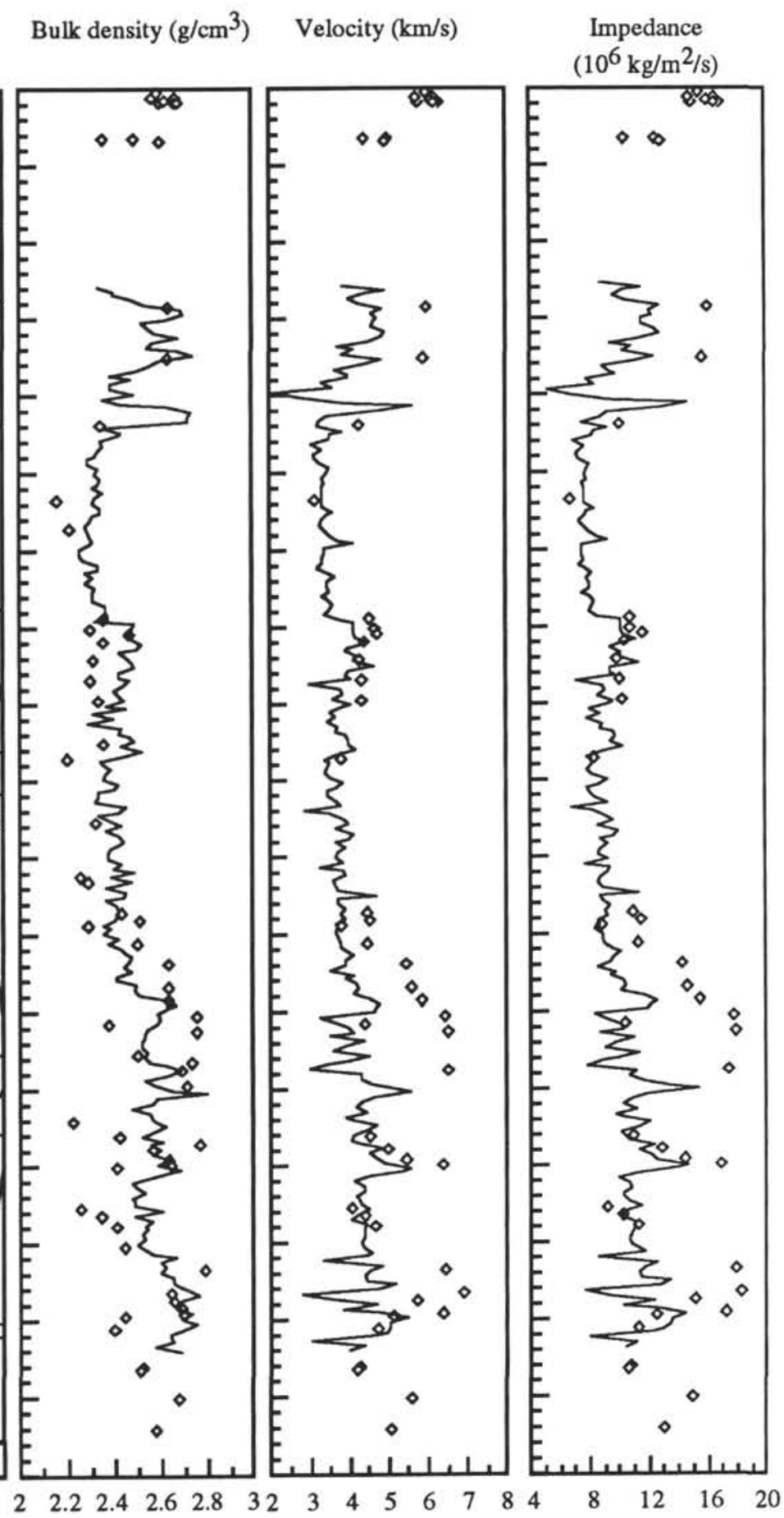

\section{LEGEND}

Rock \& Sediment Type

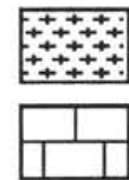

Foraminiferal nannofossil ooze

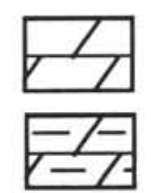

Dolomite

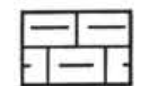

Clayey limestone

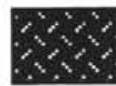

Basalt

Limestone

Clayey dolomite

Figure 1. Simplified lithologic column along with smoothed sonic, neutron density, and impedance logs and discrete measurements of vertical compressional wave velocity, $V_{p l}$ (under effective pressure), bulk density, and calculated impedance (diamonds) for Sites 866 (A) and 869 (B). Processed logs have been smoothed by applying a five-point $(0.61 \mathrm{~m}$ or $2 \mathrm{ft})$ moving average window and resampled to a $6-\mathrm{m}(18 \mathrm{ft})$ interval by averaging data over $\pm 3 \mathrm{~m}(9 \mathrm{ft})$. 


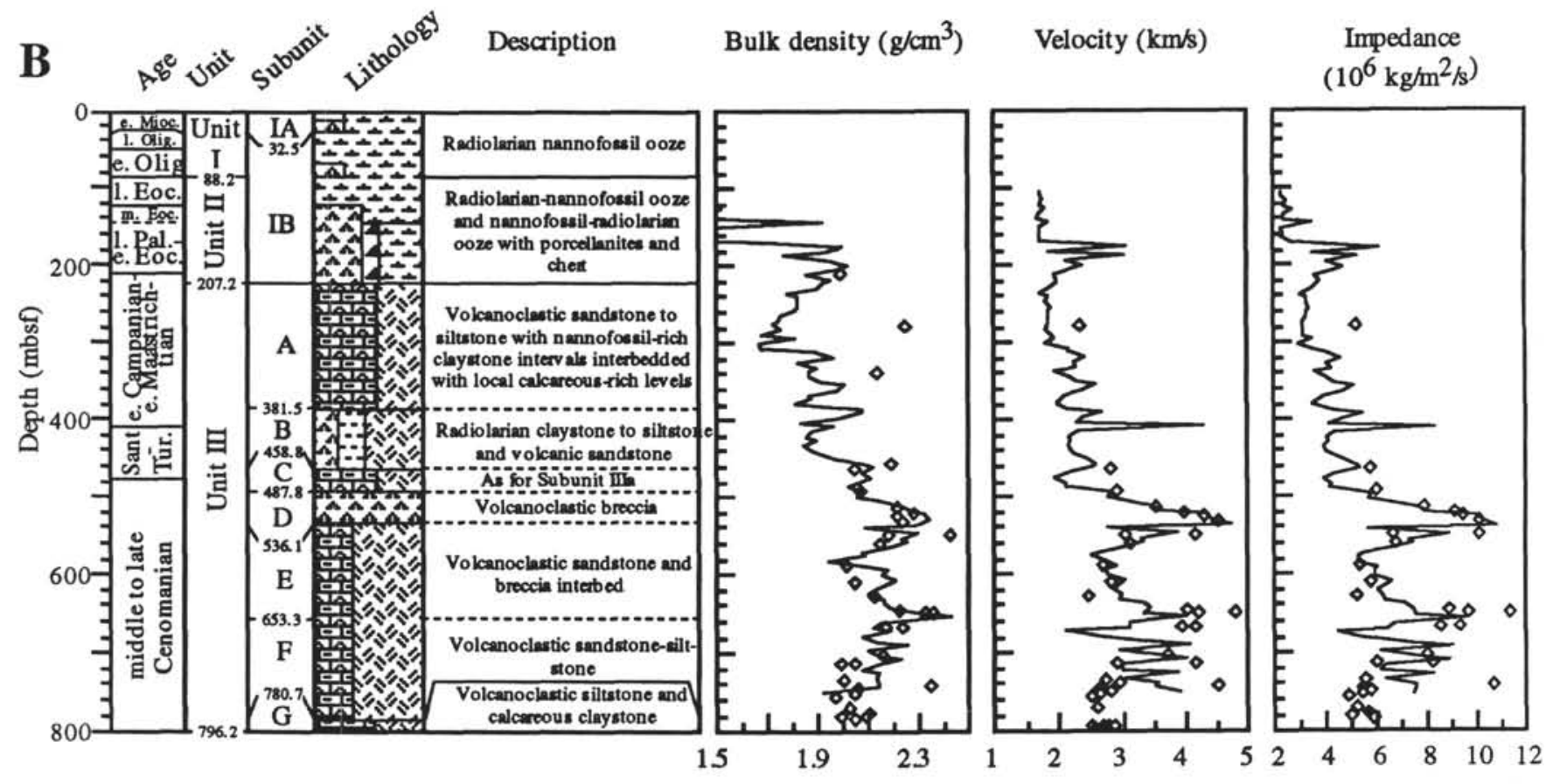

LEGEND

Rock \& Sediment Type

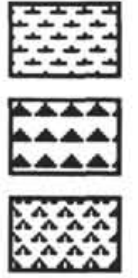

Nannofossil

ooze

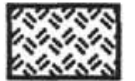

Volcanic breccia, sandstone

and siltstone

Chert

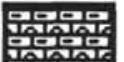

Interbedded calcareous claystone

with some radiolarians

Radiolarian ooze

Zeolitic claystone

Figure 1 (continued).

lithologies. The equation for limestone (Gardner et al., 1974), graphically depicted and fitted by a power function is,

$$
\rho=1.493 \cdot V_{p}{ }^{0.324} \text {. }
$$

Figure $5 \mathrm{~A}$ shows a crossplot of bulk density vs. acoustic velocity ( $V_{p l}$ and $V_{p t}$, from the data set from Site 866 rock specimens) along with the empirical relationship for limestone from Gardner's equation. The data from Site 866 can be fitted by a power function similar to Gardner's equation,

$$
\rho=1.489 \cdot V_{p}{ }^{0.321},
$$

with a correlation coefficient $R=0.92(N=92)$. Both Gardner's curve for limestone and the fitted power function to the data of Site 866 run through the middle of the data and have only a minor offset. Figure $5 \mathrm{C}$ shows a similar crossplot for the volcaniclastic specimens from Site 869, along with the general Gardner's equation. Velocities predicted by Gardner's curve are significantly lower than those shown by the volcaniclastic specimens.

The "time-average equation" of Wyllie et al. (1958),

$$
1 / V_{p}=\phi / V_{\text {fluid }}+(1-\phi) / V_{\text {matrix }}
$$

where $\phi$ is porosity and $V_{\text {fluid }}$ or $V_{\text {seawater }}$ is $1.5 \mathrm{~km} / \mathrm{s}$ (at $14.3^{\circ} \mathrm{C}$ and salinity of $35 \%$, see Carmichael, 1989), relates porosity to velocity. To convert the time-average equation for specimens with calcite and dolomite mineralogy we substituted 6.5 and $6.9 \mathrm{~km} / \mathrm{s}$ for $V_{\text {matrix }}$ (Carmichael, 1989), for calcite and dolomite fabrics, respectively. Figure 5B shows a crossplot of bulk porosity vs. acoustic velocity along with the time-average equation for calcite and dolomite for the data set of Site 866 rock specimens. The time-average equation for pure calcitic fabrics forms the lower limit of the data set and even the higher matrix velocity of the dolomite does not explain the observed trend. Figure 5D shows a crossplot of porosity vs. acoustic velocity along with the time-average equation for Site 869 rock specimens. In addition, curves are plotted that represent the time-average equation for different matrix velocities, ranging from highly to moderately altered basalt, 2.5 to $4.5 \mathrm{~km} / \mathrm{s}$, to fresh basalt, 4.5 to $5.5 \mathrm{~km} / \mathrm{s}$ (see Sager, Winterer, Firth, et al., 1993). Two discrete groups with different matrix velocities are present within the volcaniclastic data set. The volcaniclastic sediments at Site 869 are complex in mineral composition, as the components of the fabric vary from unaltered to highly altered volcanic glass fragments and basalt fragments. In addition, zeolite replaces original grains and locally acts as cement. Therefore, it is difficult to substitute values that represent the matrix velocity in the time-average equation. 
Table 2. Summary of index properties, acoustic properties, and characteristic petrographic groups for rock specimens from Site 866.

\begin{tabular}{|c|c|c|c|c|c|c|c|c|c|c|c|}
\hline $\begin{array}{l}\text { Core, section, } \\
\text { interval }(\mathrm{cm})\end{array}$ & $\begin{array}{l}\text { Depth } \\
\text { (mbsf) }\end{array}$ & Fabric & $\begin{array}{l}\text { Bulk density } \\
\left(\mathrm{g} / \mathrm{cm}^{3}\right)\end{array}$ & $\begin{array}{l}\text { Grain density } \\
\left(\mathrm{g} / \mathrm{cm}^{3}\right)\end{array}$ & $\begin{array}{c}\text { Porosity } \\
(\%)\end{array}$ & $\begin{array}{c}V_{p l} \\
(\mathrm{~km} / \mathrm{s})\end{array}$ & $\begin{array}{c}V_{s l} \\
(\mathrm{~km} / \mathrm{s})\end{array}$ & $\begin{array}{c}V_{p l} \\
(\mathrm{~km} / \mathrm{s})\end{array}$ & $\begin{array}{c}V_{s t} \\
(\mathrm{~km} / \mathrm{s})\end{array}$ & $V_{p i} / V_{s I}$ & $\begin{array}{l}\text { Impedance } \\
\left(10^{6} \cdot \mathrm{g} / \mathrm{m}^{2} / \mathrm{s}\right)\end{array}$ \\
\hline \multicolumn{12}{|l|}{ 143-866A- } \\
\hline $31 \mathrm{R}-1,120-122$ & 281.81 & 2 & 2.63 & & & 6.119 & 3.190 & & & 1.92 & 16.09 \\
\hline $39 \mathrm{R}-1,44-46$ & 348.15 & 3 & 2.64 & 2.71 & 6.16 & 5.932 & 4.354 & & & 1.36 & 15.66 \\
\hline $48 \mathrm{R}-1,47-51$ & 434.88 & 2 & 2.35 & 2.71 & 20.19 & 4.309 & 2.044 & & & 2.11 & 10.13 \\
\hline $58 \mathrm{R}-1,67-71$ & 531.69 & 2 & 2.16 & 2.60 & 27.73 & 3.158 & 1.415 & & & 2.23 & 6.82 \\
\hline $62 R-2,5-7$ & 571.16 & 4 & 2.22 & 2.71 & 28.14 & & & 3.260 & 1.737 & & \\
\hline $74 \mathrm{R}-1,20-27^{\circ}$ & 685.76 & la & 2.36 & 2.71 & 21.24 & 4.544 & 1.981 & 4.175 & 2.124 & 2.29 & 10.72 \\
\hline $75 \mathrm{R}-3,53-64^{\circ}$ & 698.59 & $1 \mathrm{a}$ & 2.30 & 2.77 & 26.63 & 4.680 & 2.380 & \multirow{2}{*}{4.274} & \multirow{2}{*}{1.774} & 1.97 & 10.76 \\
\hline $76 \mathrm{R}-3,37-40$ & 708.09 & la & 2.47 & 2.73 & 14.89 & 4.751 & 2.193 & & & 2.17 & 11.73 \\
\hline $77 \mathrm{R}-2,87-93^{\circ}$ & 716.90 & la & 2.36 & 2.70 & 20.96 & 4.425 & 1.987 & \multirow{2}{*}{4.146} & \multirow{2}{*}{1.851} & 2.23 & 10.44 \\
\hline $79 \mathrm{R}-4,2-10^{\circ}$ & 738.15 & la & 2.32 & 2.72 & 24.74 & 4.271 & 2.070 & & & 2.06 & 9.91 \\
\hline $82 R-2,62-68^{*}$ & 764.83 & la & 2.31 & 2.72 & 25.11 & 4.370 & 2.406 & \multicolumn{2}{|c|}{$\begin{array}{ll}3.800 & 1.888 \\
3.818 & 2.016\end{array}$} & 1.82 & 10.09 \\
\hline $85 R-2,45-55^{\circ}$ & 793.81 & $1 \mathrm{a}$ & 2.34 & 2.71 & 21.30 & 4.357 & 2.862 & \multirow{2}{*}{\multicolumn{2}{|c|}{$\begin{array}{ll}4.187 & 2.703 \\
4.227 & 1.776\end{array}$}} & 1.52 & 10.20 \\
\hline $91 \mathrm{R}-1,6-8$ & 849.57 & 3 & 2.36 & 2.71 & 20.72 & & & & & & \\
\hline $93 \mathrm{R}-1,21-28^{\circ}$ & 868.95 & $6 \mathrm{~b}$ & 2.20 & 2.73 & 31.35 & 3.818 & 1.177 & 4.427 & 2.534 & 3.24 & 8.40 \\
\hline $102 \mathrm{R}-1,78-80$ & 953.49 & la & 2.33 & 2.71 & 23.07 & & & 3.828 & 2.389 & & \\
\hline $109 \mathrm{R}-2,10-12$ & 1021.51 & 2 & 2.26 & 2.72 & 26.12 & & & 3.760 & 1.936 & & \\
\hline $110 \mathrm{R}-1,53-55$ & 1030.14 & 2 & 2.29 & 2.73 & 25.37 & & & 3.750 & 2.219 & & \\
\hline $114 \mathrm{R}-1,85-87$ & 1069.02 & 2 & 2.44 & 2.74 & 17.53 & 4.502 & 3.196 & & & 1.41 & 10.98 \\
\hline $115 \mathrm{R}-1,76-78$ & 1078.67 & 3 & 2.51 & 2.74 & 12.52 & 4.584 & 2.353 & & & 1.95 & 11.51 \\
\hline $116 \mathrm{R}-1,49-51$ & 1088.00 & 2 & 2.29 & 2.73 & 25.19 & 3.841 & 2.500 & 3.513 & 1.824 & 1.54 & 8.80 \\
\hline $118 \mathrm{R}-2,138-143$ & 1109.70 & $5 a$ & 2.50 & & & 4.510 & 2.810 & & & 1.60 & 11.28 \\
\hline $121 \mathrm{R}-1,31-34$ & 1136.03 & $5 \mathrm{a}$ & 2.64 & 2.79 & 8.85 & 5.453 & 3.684 & & & 1.48 & 14.40 \\
\hline $124 \mathrm{R}-1,30-33$ & 1165.22 & $5 a$ & 2.63 & 2.76 & 7.13 & 5.586 & 4.124 & & & 1.35 & 14.69 \\
\hline $126 \mathrm{R}-1,54-56$ & 1184.55 & $1 \mathrm{~b}$ & 2.63 & 2.73 & 5.77 & 5.893 & 3.045 & & & 1.94 & 15.50 \\
\hline 128R-2, 0-9 & 1204.75 & $5 b$ & 2.76 & 2.86 & 5.12 & 6.452 & 3.242 & 6.253 & 3.152 & 1.99 & 17.81 \\
\hline $129 R-2,23-26$ & 1213.15 & 1a & 2.38 & 2.85 & 22.62 & 4.404 & 3.237 & & & 1.36 & 10.48 \\
\hline $130 \mathrm{R}-2,20-26$ & 1224.33 & $5 \mathrm{~b}$ & 2.76 & 2.75 & 1.45 & 6.514 & 3.774 & 6.216 & 2.180 & 1.73 & 17.98 \\
\hline $133 \mathrm{R}-2,54-57$ & 1253.66 & $5 c$ & 2.50 & 2.83 & 19.25 & & & 5.438 & 2.949 & & \\
\hline $134 \mathrm{R}-2,67-70$ & 1263.39 & $5 b$ & 2.74 & 2.84 & 5.31 & & & 6.498 & 3.162 & & \\
\hline $135 \mathrm{R}-1,113-116$ & 1272.05 & $5 b$ & 2.69 & 2.84 & 9.38 & 6.510 & 3.191 & & & 2.04 & 17.51 \\
\hline $137 \mathrm{R}-2,79-81$ & 1292.10 & $5 b$ & 2.71 & 2.84 & 6.62 & & & 6.500 & 3.312 & & \\
\hline $142 \mathrm{R}-1,89-91$ & 1339.10 & $5 \mathrm{c}$ & 2.23 & 2.88 & 30.01 & & & 4.759 & 2.416 & & \\
\hline $144 \mathrm{R}-2,51-59^{\circ}$ & 1359.55 & $1 \mathrm{a}$ & 2.43 & 2.71 & 16.95 & 4.545 & 2.384 & 4.396 & 3.162 & 1.91 & 11.04 \\
\hline $145 \mathrm{R}-1,131-134$ & 1368.13 & $5 b$ & 2.77 & 2.79 & 1.29 & & & 6.671 & 4.985 & & \\
\hline $146 \mathrm{R}-1,79-81$ & 1377.20 & 4 & 2.57 & 2.72 & 8.51 & 4.993 & 2.119 & & & 2.36 & 12.83 \\
\hline $147 \mathrm{R}-2,91-93$ & 1388.52 & 2 & 2.64 & 2.72 & 4.43 & 5.490 & 3.518 & & & 1.56 & 14.49 \\
\hline $148 \mathrm{R}-1,55-58$ & 1396.27 & $5 \mathrm{~b}$ & 2.65 & 2.86 & 10.14 & 6.377 & 3.188 & & & 2.00 & 16.90 \\
\hline $148 R-4,95-98$ & 1401.17 & 1a & 2.42 & 2.76 & 17.60 & & & 4.727 & 2.026 & & \\
\hline $154 \mathrm{R}-1,63-70^{\circ}$ & 1454.47 & $1 \mathrm{a}$ & 2.26 & 2.73 & 27.22 & 4.093 & 2.047 & 3.662 & 1.486 & 2.00 & 9.25 \\
\hline $155 \mathrm{R}-1,91-98^{\circ}$ & 1464.45 & $1 \mathrm{a}$ & 2.35 & 2.76 & 22.12 & 4.398 & 2.175 & 4.094 & 2.347 & 2.02 & 10.34 \\
\hline $156 \mathrm{R}-2,57-61$ & 1475.28 & $6 a$ & 2.41 & 2.72 & 17.74 & 4.672 & 2.893 & & & 1.61 & 11.26 \\
\hline $159 \mathrm{R}-1,99-101$ & 1501.90 & 2 & 2.45 & 2.77 & 17.37 & & & 4.093 & 2.047 & & \\
\hline $162 \mathrm{R}-2,2-5$ & 1532.53 & $5 b$ & 2.79 & 2.83 & 2.75 & 6.487 & 3.892 & & & 1.67 & 18.10 \\
\hline $165 R-2,71-75$ & 1561.83 & $5 b$ & 2.65 & 2.82 & 8.23 & 6.944 & 3.545 & & & 1.96 & 18.40 \\
\hline $166 \mathrm{R}-4,85-98$ & 1574.67 & $5 \mathrm{c}$ & 2.66 & 2.77 & 6.60 & 5.714 & 3.509 & & & 1.63 & 15.20 \\
\hline $167 \mathrm{R}-3,101-103$ & 1584.42 & $5 \mathrm{~b}$ & 2.69 & 2.85 & 7.97 & & & 6.649 & 3.387 & & \\
\hline $168 \mathrm{R}-1,128-134^{\circ}$ & 1591.41 & $5 b$ & 2.70 & 2.81 & 6.21 & 6.391 & 3.482 & 6.447 & 3.390 & 1.84 & 17.26 \\
\hline $168 \mathrm{R}-3,72-74$ & 1593.83 & $5 \mathrm{c}$ & 2.45 & & & 5.130 & 2.706 & & & 1.90 & 12.57 \\
\hline $170 \mathrm{R}-1,109-118^{\circ}$ & 1610.55 & la & 2.40 & 2.74 & 18.83 & 4.748 & 2.470 & 4.381 & 2.370 & 1.92 & 11.40 \\
\hline $179 \mathrm{R}-1,71-75$ & 1660.13 & 7 & 2.53 & 2.80 & 14.94 & 4.274 & 2.151 & & & 1.99 & 10.81 \\
\hline $179 \mathrm{R}-2,108-119$ & 1661.64 & 7 & 2.51 & 2.79 & 15.99 & 4.247 & 1.807 & 4.204 & 1.998 & 2.35 & 10.66 \\
\hline $185 R-3,51-54$ & 1700.83 & 7 & 2.68 & 2.92 & 10.60 & 5.598 & 3.620 & & & 1.55 & 15.00 \\
\hline $189 \mathrm{R}-4,33-36$ & 1739.63 & 7 & 2.58 & 2.83 & 14.28 & 5.078 & 3.001 & & & 1.69 & 13.10 \\
\hline 143-866B- & & & & & & & & & & & \\
\hline $8 \mathrm{M}-1,69-71$ & 61.80 & $6 \mathrm{~b}$ & 2.49 & 2.72 & 14.05 & 5.026 & 2.178 & & & 2.31 & 12.51 \\
\hline $8 \mathrm{M}-2,9-11$ & 62.70 & $6 b$ & & 2.36 & 2.72 & 20.40 & 4.395 & 2.107 & & 2.09 & 10.37 \\
\hline 143-867B- & & & & & & & & & & & \\
\hline $1 R-2,47-49$ & 1.98 & $6 c$ & 2.59 & 2.72 & 9.75 & 5.977 & 3.427 & & & 1.74 & 15.48 \\
\hline $3 \mathrm{R}-1,82-85$ & 15.94 & $6 c$ & 2.60 & 2.72 & 8.24 & 5.774 & 2.683 & & & 2.15 & 15.01 \\
\hline $10 \mathrm{R}-1,27-36$ & 66.72 & $6 b$ & 2.60 & 2.72 & 8.25 & 4.978 & 2.811 & 5.618 & 2.448 & 1.77 & 12.94 \\
\hline $143-868 \mathrm{~A}-$ & & & & & & & & & & & \\
\hline $2 \mathrm{R}-1,72-75$ & 8.74 & $6 b$ & 2.57 & 2.72 & 9.14 & 5.747 & 2.874 & & & 2.00 & 14.77 \\
\hline $2 \mathrm{R}-2,69-71$ & 10.20 & $6 c$ & 2.67 & 2.72 & 3.45 & 6.220 & 3.274 & & & 1.90 & 16.61 \\
\hline $4 \mathrm{R}-2,8-13$ & 14.56 & $6 c$ & & 2.62 & 2.72 & 7.82 & 6.160 & 2.781 & & 2.22 & 16.14 \\
\hline $4 R-2,52-56$ & 15.00 & $6 c$ & 2.67 & 2.72 & 2.38 & 6.340 & 3.973 & & & 1.60 & 16.93 \\
\hline $5 \mathrm{R}-1,75-77$ & 17.96 & $6 c$ & 2.68 & 2.72 & 1.93 & 6.196 & 3.297 & & & 1.88 & 16.61 \\
\hline
\end{tabular}

Notes: ${ }^{*}=$ Pairs of both longitudinal and transverse oriented minicores within identical layer and spaced less than $15 \mathrm{~cm}$ apart; $V_{p l}=$ vertical compressional velocity; $V_{s l}=$ vertical shear-wave velocity; $V_{p t}=$ transverse compressional velocity; $V_{s t}=$ transverse shear-wave velocity; $V_{p l} / V_{s l}=$ ratio of vertical compressional velocity over vertical shear-wave velocity. See text for discussion.

\section{$V_{p l}$ and $V_{p} / V_{s}$ vs. Porosity \\ (Data Sets Discriminated for Petrography)}

Figures $6 \mathrm{~A}$ and $6 \mathrm{~B}$ show crossplots for porosity and longitudinal compressional velocity for Sites 866 and 869 , respectively. Here, the rock specimens are labeled according to their petrographic character, as explained in Table 1 and summarized in Tables 2 and 3 . The basalt specimens from Site 866 have been plotted with the volcaniclastic specimens from Site 869 in Figure 6B. Plotted along with the data set of Site 866 are curves that represent the time-average equation for calcite and dolomite matrices (Fig. 6A). Similarly, a series of curves representing the time-average equation for matrix velocities ranging from 2.5 to $7.5 \mathrm{~km} / \mathrm{s}$ in steps of $0.5 \mathrm{~km} / \mathrm{s}$, are plotted with the data from Site 869 (Fig. 6B).

Measurements of oolitic to skeletal grainstones with open interparticle porosity (Pl. 1, Fig. 8) show that velocity is directly related to porosity, grain size and grain packing (Fig. 6A, open triangles). Cementation of the grainstone and rudstone (Pl. 1, Fig. 2) reduces the 
Table 3. Summary of index properties, acoustic properties and characteristic petrographic groups for rock specimens from Site 869.

\begin{tabular}{|c|c|c|c|c|c|c|c|c|c|c|c|}
\hline $\begin{array}{l}\text { Core, section, } \\
\text { interval }(\mathrm{cm})\end{array}$ & $\begin{array}{l}\text { Depth } \\
\text { (mbsf) }\end{array}$ & Fabric & $\begin{array}{l}\text { Bulk density } \\
\left(\mathrm{g} / \mathrm{cm}^{3}\right)\end{array}$ & $\begin{array}{l}\text { Grain density } \\
\left(\mathrm{g} / \mathrm{cm}^{3}\right)\end{array}$ & $\begin{array}{l}\text { Porosity } \\
(\%)\end{array}$ & $\begin{array}{c}V_{p l} \\
(\mathrm{~km} / \mathrm{s})\end{array}$ & $\begin{array}{r}\begin{array}{r}V_{s l} \\
(\mathrm{~km} / \mathrm{s})\end{array} \\
\end{array}$ & $\begin{array}{c}\begin{array}{c}V_{t} \\
(\mathrm{~km} / \mathrm{s})\end{array}\end{array}$ & $\begin{array}{c}\begin{array}{c}V_{s t} \\
(\mathrm{~km} / \mathrm{s})\end{array} \\
-\end{array}$ & $V_{p l} / V_{s l}$ & $\begin{array}{l}\text { Impedance } \\
\left(10^{6} \cdot \mathrm{kgm}^{2} \mathrm{~s}\right)\end{array}$ \\
\hline \multicolumn{12}{|l|}{ 143-869B- } \\
\hline 9R-CC, 3-5 & 207.64 & 8 & 1.99 & 2.25 & 23.12 & & & 3.226 & 1.792 & & \\
\hline $16 \mathrm{R}-1,92-94$ & 276.03 & 8 & 2.24 & 2.81 & 39.38 & 2.334 & 0.979 & & & 2.38 & 5.23 \\
\hline $22 \mathrm{R}-3,0-4$ & 335.62 & 8 & 2.13 & 2.66 & 35.92 & & & 2.704 & 1.144 & & \\
\hline $34 \mathrm{R}-2,107-110$ & 451.68 & 8 & 2.19 & 2.72 & 38.18 & & & 2.346 & 0.946 & & \\
\hline $35 R-1,24-26$ & 459.05 & 2 & 2.05 & 2.48 & 30.25 & 2.822 & 1.265 & & & 2.23 & 5.78 \\
\hline $38 \mathrm{R}-2,25-27$ & 488.60 & $9 \mathrm{a}$ & 2.07 & 2.60 & 37.46 & 2.914 & 0.947 & & & 3.08 & 6.03 \\
\hline $40 \mathrm{R}-2,36-42^{\circ}$ & 508.99 & $10 \mathrm{a}$ & 2.21 & 2.63 & 28.05 & 3.555 & 1.696 & 3.716 & 1.527 & 2.10 & 7.86 \\
\hline $41 \mathrm{R}-2,114-118$ & 517.96 & $10 \mathrm{~b}$ & 2.28 & 2.56 & 21.07 & 3.994 & 1.715 & & & 2.33 & 9.11 \\
\hline $41 R-4,5-7^{*}$ & 520.98 & $10 \mathrm{~b}$ & 2.21 & 2.48 & 23.03 & 4.294 & 2.076 & 4.492 & 1.615 & 2.07 & 9.49 \\
\hline $42 \mathrm{R}-1,107-116^{*}$ & 527.51 & $10 \mathrm{~b}$ & 2.23 & 2.51 & 23.22 & 4.545 & 1.954 & 4.857 & 2.006 & 2.33 & 10.14 \\
\hline $44 \mathrm{R}-1,101-105$ & 546.63 & $10 \mathrm{~b}$ & 2.42 & 2.72 & 19.47 & 4.185 & 1.949 & & & 2.15 & 10.13 \\
\hline $44 \mathrm{R}-2,18-19$ & 547.29 & $9 \mathrm{a}$ & 2.18 & 2.66 & 31.97 & 3.074 & 2.002 & & & 1.54 & 6.70 \\
\hline $45 \mathrm{R}-2,49-65^{\circ}$ & 557.17 & $9 \mathrm{a}$ & 2.15 & 2.69 & 34.01 & 3.147 & 1.328 & 3.200 & 1.299 & 2.37 & 6.77 \\
\hline $48 \mathrm{R}-1,40-44$ & 584.32 & $9 \mathrm{a}$ & 2.01 & 2.70 & 43.61 & 2.680 & 1.923 & & & 1.39 & 5.39 \\
\hline $50 \mathrm{R}-3,7-13^{\circ}$ & 606.30 & $9 \mathrm{a}$ & 2.05 & 2.71 & 40.39 & 2.845 & 1.996 & 2.955 & 1.919 & 1.43 & 5.83 \\
\hline $52 \mathrm{R}-3,2-8^{\circ}$ & 625.46 & 3 & 2.12 & 2.58 & 32.73 & 2.488 & 1.406 & 2.660 & 1.091 & 1.77 & 5.27 \\
\hline $54 \mathrm{R}-1,93-99^{*}$ & 642.77 & $10 \mathrm{~b}$ & 2.22 & 2.56 & 24.70 & 4.029 & 1.715 & 4.374 & & 2.35 & 8.94 \\
\hline $54 \mathrm{R}-4,32-41^{\circ}$ & 646.35 & $10 \mathrm{~b}$ & 2.32 & 2.63 & 20.91 & 4.221 & 2.007 & 4.956 & 2.663 & 2.10 & 9.71 \\
\hline $54 \mathrm{R}-4,116-119$ & 647.19 & $10 \mathrm{~b}$ & 2.36 & 2.49 & 12.47 & 4.808 & 2.071 & & & 2.32 & 11.35 \\
\hline $56 \mathrm{R}-2,113-115$ & 663.84 & $9 \mathrm{~b}$ & 2.23 & 2.42 & 17.37 & 4.188 & 2.451 & & & 1.71 & 9.34 \\
\hline $56 \mathrm{R}-3,68-70$ & 664.89 & $9 \mathrm{~b}$ & 2.17 & 2.44 & 21.58 & 3.939 & 2.118 & & & 1.86 & 8.55 \\
\hline $59 \mathrm{R}-6,57-63^{\circ}$ & 698.11 & $9 \mathrm{~b}$ & 2.16 & 2.46 & 24.67 & 3.717 & 1.832 & 3.721 & 1.811 & 2.03 & 8.03 \\
\hline $61 \mathrm{R}-1,37-44^{\circ}$ & 709.82 & $9 \mathrm{a}$ & 2.05 & 2.56 & 36.67 & 2.912 & 1.304 & 3.100 & 1.450 & 2.23 & 5.97 \\
\hline $61 \mathrm{R}-2,41-48^{\circ}$ & 711.34 & $9 \mathrm{~b}$ & 1.99 & 2.45 & 27.93 & 4.150 & 2.466 & 4.221 & 2.631 & 1.68 & 8.26 \\
\hline $63 \mathrm{R}-3,28-31$ & 732.00 & 8 & 2.00 & 2.58 & 38.35 & 2.760 & 1.380 & & 2.001 & 2.00 & $\begin{array}{l}0.20 \\
5.52\end{array}$ \\
\hline $63 R-4,81-85$ & 734.04 & $9 \mathrm{a}$ & & & & 2.947 & 1.278 & & & 2.31 & \\
\hline $63 \mathrm{R}-\mathrm{CC}, 2-4$ & 738.34 & $9 \mathrm{~b}$ & 2.35 & 2.47 & 11.70 & 4.541 & & & & & 10.67 \\
\hline $64 \mathrm{R}-3,113-116$ & 742.55 & 8 & 2.06 & 2.65 & 38.28 & 2.656 & 1.173 & & & 2.26 & 5.47 \\
\hline $64 \mathrm{R}-6,57-60$ & 746.49 & 8 & 2.04 & 2.71 & 40.51 & 2.833 & 1.256 & & & 2.26 & 5.78 \\
\hline $65 \mathrm{R}-1,70-73$ & 748.62 & 8 & 2.04 & 2.70 & 40.84 & 2.646 & 1.439 & & & 1.84 & 5.40 \\
\hline $65 R-4,3-7$ & 752.45 & 8 & 1.97 & 2.68 & 55.85 & 2.508 & 1.173 & & & 2.14 & 4.94 \\
\hline $67 \mathrm{R}-1,146-149$ & 768.78 & 8 & 2.02 & 2.64 & 40.09 & 2.590 & 1.179 & & & 2.20 & 5.23 \\
\hline 67R-CC, $2-5$ & 775.68 & 8 & 2.10 & 2.76 & 38.71 & 2.702 & 1.367 & & & 1.98 & 5.67 \\
\hline $68 \mathrm{R}-1,60-63$ & 777.51 & $9 \mathrm{a}$ & 1.99 & 2.64 & 42.30 & 2.497 & 1.389 & & & 1.80 & 4.97 \\
\hline $68 \mathrm{R}-2,44-47$ & 778.89 & 8 & 2.09 & 2.68 & 36.50 & 2.784 & 1.240 & & & 2.25 & 5.82 \\
\hline $68 \mathrm{R}-3,53-57$ & 780.45 & 8 & 2.05 & 2.68 & 36.84 & 2.880 & 1.376 & & & 2.09 & 5.90 \\
\hline
\end{tabular}

Note: ${ }^{*}=$ Pairs of both longitudinal and transverse oriented minicores within identical layer and spaced less than $15 \mathrm{~cm}$ apart $; V_{p l}=$ vertical compressional velocity; $V_{s l}=$ vertical shear-wave velocity; $V_{p t}=$ transverse compressional velocity; $V_{s t}=$ transverse shear-wave velocity; $V_{p l} / V_{s l}=$ ratio of vertical compressional velocity over vertical shear-wave velocity. See text for discussion. 

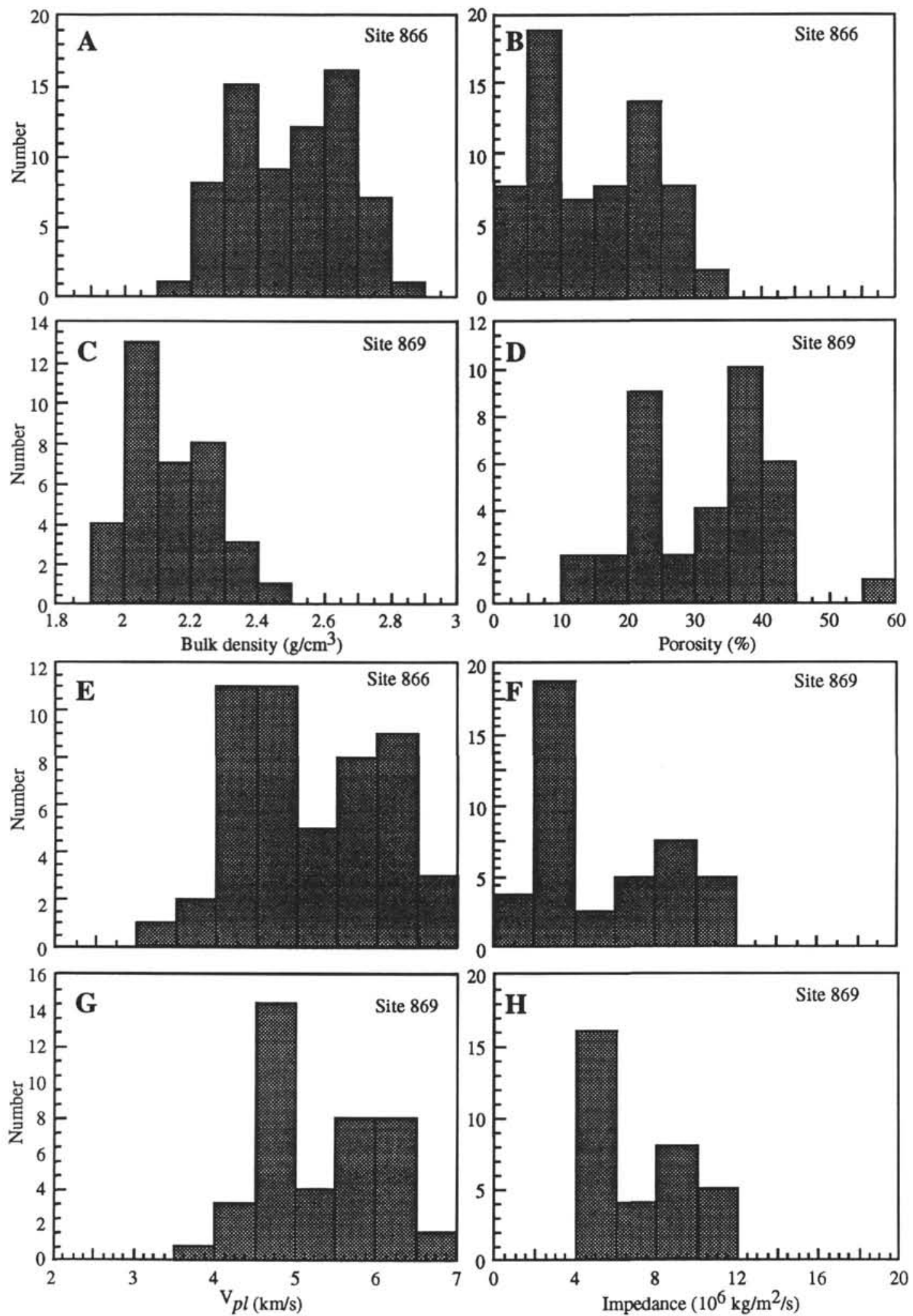

Figure 2. Histograms of bulk density (A, C), porosity (B, D), vertical compressional velocity $(\mathbf{E}, \mathbf{G})$, and impedance $(\mathbf{F}, \mathbf{H})$ for rock specimens from Sites 866 and 869 . See text for discussion. 
porosity and consequently increases velocity from 4.2 to $4.8 \mathrm{~km} / \mathrm{s}$ (Fig. $6 \mathrm{~A}$, open triangles and circles), to 5.7 to $5.9 \mathrm{~km} / \mathrm{s}$ (Fig. 6A, solid triangles and circles). Dense packstone, wackestone, and mudstone with low micro porosity (PI. 1, Fig. 3) have comparable velocity, ranging from 5 to $6 \mathrm{~km} / \mathrm{s}$, and low porosities, ranging from $5 \%$ to $5.8 \%$. The pres- ence of micrite as matrix (PI. 1, Fig. 4) has a similar influence on the velocity (Fig. 6A, solid circles). In contrast, the leaching of skeletal components to create moldic porosity (Pl. 1, Fig. 5 ), decreases the velocity (Fig. 6A, open circles with dot). One rudstone specimen with a high interparticle porosity of $18 \%$ and partial replacement by dolomite has a velocity of $5.7 \mathrm{~km} / \mathrm{s}$ (Pl. 1, Fig. 6). The effect of the replacement of grains or matrix, and/or cementation, by dolomite is illustrated in the data set in two stages. Partial replacement of grains by dolomite in an ooid rudstone (Pl. 1, Fig. 7) has little effect on the velocity (Fig. 6A, open circle). Dolomite cementation of grainstones significantly increases the velocity from 4.2 to $4.8 \mathrm{~km} / \mathrm{s}$ (Fig. $6 \mathrm{~A}$, open triangles) to $5.4 \mathrm{~km} / \mathrm{s}$ (Fig. 6A, squares with dot). Complete recrystallization of grainstones by dolomite increases velocity up to 6.4 and 7 km/s (Fig. 6A, solid squares; Pl. 1, Fig. 8).

Volcaniclastic rock specimens from Site 869 on average exhibit higher porosity and lower velocity and show a clear subdivision into two separate groups (solid vs. open symbols, Fig. 6B). Clayey packstone to wackestone rock specimens have high microporosities of $30 \%$ to $33 \%$, and low velocity of 2.5 to $2.8 \mathrm{~km} / \mathrm{s}$. Volcaniclastic siltstones that have altered grains (Pl. 2, Fig. 1), and high interparticle and intercrystalline porosity ( $36 \%$ to $56 \%$ ) have low velocities, ranging from 2.3 to $2.8 \mathrm{~km} / \mathrm{s}$. Similar, altered sand-sized fabrics (Pl. 2, Fig. 2) have slightly higher velocity and porosity of 2.5 to $3.2 \mathrm{~km} / \mathrm{s}$ and $32 \%$ to $44 \%$, respectively. Sandstones that have predominantly unaltered grains and zeolite partially replacing and cementing the components (see Pl. 2, Fig. 3) have significantly higher porosity and higher velocity of $12 \%$ to $28 \%$ and 3.6 to $4.6 \mathrm{~km} / \mathrm{s}$, respectively. Volcaniclastic breccia that has altered components and high interparticle and intercrystalline porosity $(28 \%)$ has a velocity of $3.6 \mathrm{~km} / \mathrm{s}$. Breccias of nonaltered grains with zeolite as replacing and cementing agent (see Pl. 2, Fig. 4) have comparable porosity and velocity to their sand-sized equivalents of $12 \%$ to $24 \%$ and 4 to $4.8 \mathrm{~km} / \mathrm{s}$, respectively. Basalt specimens show little alteration and have velocities ranging from 4.2 to $5.6 \mathrm{~km} / \mathrm{s}$ and porosities between $10 \%$ and $16 \%$.

Figure 7A shows a crossplot of $V_{p l} / V_{s l}$ vs. $V_{p l}$ for rock specimens from Site 866. Overall, $V_{p l} / V_{s l}$ ranges from 1.35 to 2.35 and $V_{p l}$ ranges from 3.8 to $7 \mathrm{~km} / \mathrm{s}$. Besides the clustering of dolomitic specimens (solid squares), the data points seem to be randomly distributed, and no trend is visible. A similar situation is seen in Figure 7B, where $V_{p l} / V_{s l}$ ranges from 1.4 to 2.4 and $V_{p l}$ ranges from 2.3 to $5.6 \mathrm{~km} / \mathrm{s}$. In contrast to the observations of Rafavich (1984), no obvious relationship between mineralogy and $V_{p} / V_{s}$ is visible.

Carbonates at Site 866 range between $6.8 \times 10^{6}$ and $18.4 \times 10^{6}$ $\mathrm{kg} / \mathrm{m}^{2} / \mathrm{s}$, whereas the acoustic impedance of the basalt ranges from 10.8 to $13.1 \times 10^{6} \mathrm{~kg} / \mathrm{m}^{2} / \mathrm{s}$ (see Tables 2 and 3). Because of the overlapping values, the contact between the carbonate sequence and the underlying basaltic basement at Site 866 , and possibly other mid-Cretaceous guyots of the western Pacific, may well be invisible in seismic-reflection profiles. However, uncertainties exist as to the whether our impedance values for the basalt are accurate. Nonaltered marine basalts may have impedance values between $12 \times 10^{6}$ and 18 $\times 10^{6} \mathrm{~kg} / \mathrm{m}^{2} / \mathrm{s}$ (e.g., see Carmichael, 1989). Impedance values from the sonic and density logs are about $10 \times 10^{6} \mathrm{~kg} / \mathrm{m}^{2} / \mathrm{s}$, whereas values from discrete measurements range between $10.8 \times 10^{6}$ and $16.35 \times$ $10^{6} \mathrm{~kg} / \mathrm{m}^{2} / \mathrm{s}$ (including measurements of samples from the deeper, not logged, portion of the basalt interval).

Impedance values for Site 869 show two peaks (histogram of Fig. $2 \mathrm{G})$ with values respective of $4 \times 10^{6}$ to $6 \times 10^{6}$ and $8 \times 10^{6}$ to $12 \times$ $10^{6} \mathrm{~kg} / \mathrm{m}^{2} / \mathrm{s}$ that correspond to the two clusters of petrophysical and petrographic groups of diagenetically altered and nonaltered rock specimens. In summary, we suggest that impedance, at both Sites 866
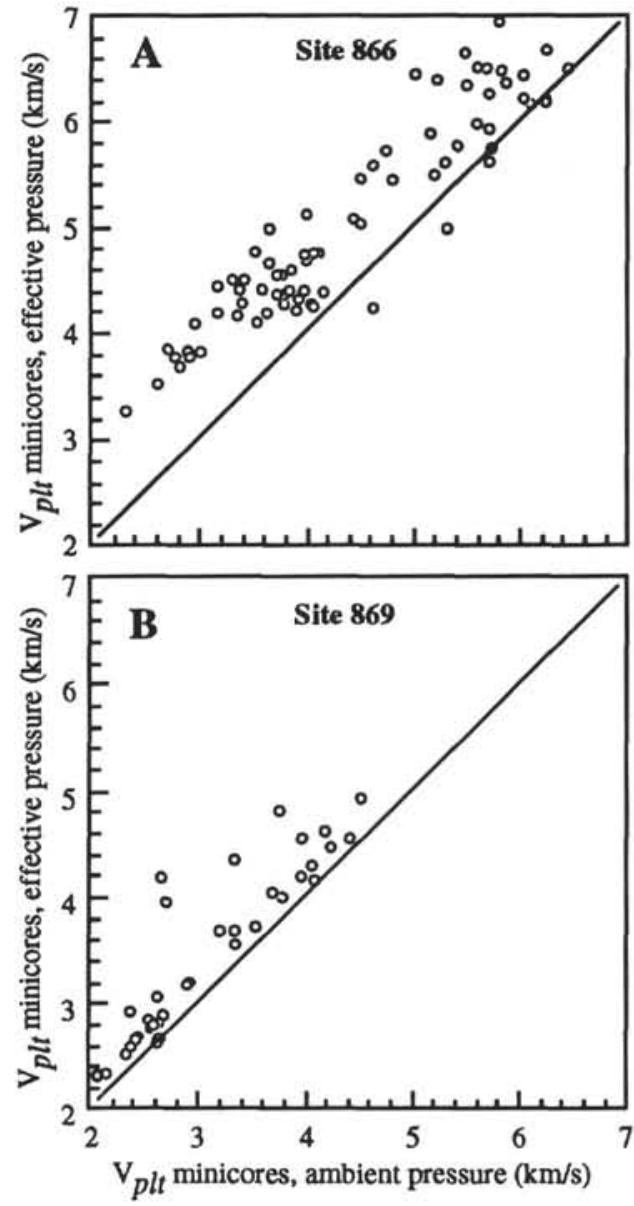

Figure 3. Crossplots of $V_{p l}$ and $V_{p t}$ measured under atmospheric pressure on minicores vs. $V_{p l}$ and $V_{p t}$ measured under effective pressure simulating in-situ conditions. A. Site 866. B. Site 869. See text for discussion.

and 869 , is controlled largely by diagenesis, rather than by primary depositional texture.

\section{$V_{p} / V_{s}$ Velocity Ratio}

The ratio of the velocity of compressional waves, $V_{p}$, to the velocity of shear waves, $V_{s}$, is an important parameter for discriminating lithology and differentiating between water and gas saturations (Gregory, 1977; Tatham and Stoffa, 1976; Hamilton, 1979; Tatham, 1982). Recently, Rafavich et al. (1984) suggested that $V_{p} / V_{s}$ velocity ratios discriminate mineralogy in limestones (specifically calcite vs. dolomite) and Wilkens et al. (1984) showed that carbonate content dominates $V_{p} / V_{s}$ in siliceous limestones.

Figure 7 shows crossplots of $V_{p l} / V_{s l}$ vs. $V_{p l}$ for rock specimens from Sites 866 and 869 . Overall, $V_{p l} / V_{s l}$ ranges from 1.35 to 2.35 and $V_{p l}$ ranges from 3.8 to $7 \mathrm{~km} / \mathrm{s}$. No trend is visible that indicates any correlation between rock fabric or mineralogy, calcite-dolomite, as suggested by Rafavich et al. (1984) for carbonates (Figs. 7A and 8). Nor does Figure 7B show any significant trends for the volcaniclastic data. Literature values for $V_{p l} / V_{s l}$ in carbonates are between 1.7 and 2.7 (Hamilton, 1979; Wilkens, 1984). High values of $V_{p l} / V_{s l}$ ratios in Figure 7 may be the result of erroneous readings of the first arrivals of the shear waves.

$V_{p l} / V_{s l}$ ratios for basalt range from 1.55 to 2.35 , with the higher values corresponding to the higher velocity specimens, though porosity shows minimal variation. Literature values range from 1.86 to 2.04 (Christensen and Salisbury, 1975; Hamilton, 1979). Note that the 

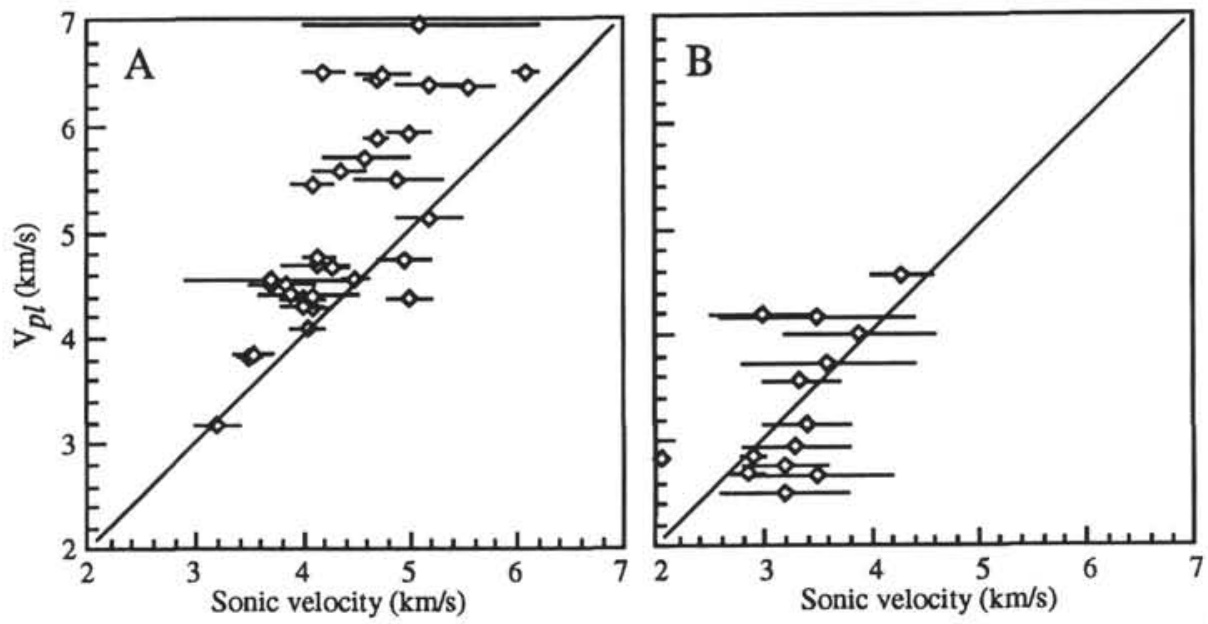

Figure 4. The correlation between acoustic velocity estimated from the sonic log and measurements of $V_{p l}$ under effective pressure for Site 866 (A) and Site 869 (B). See text for discussion.
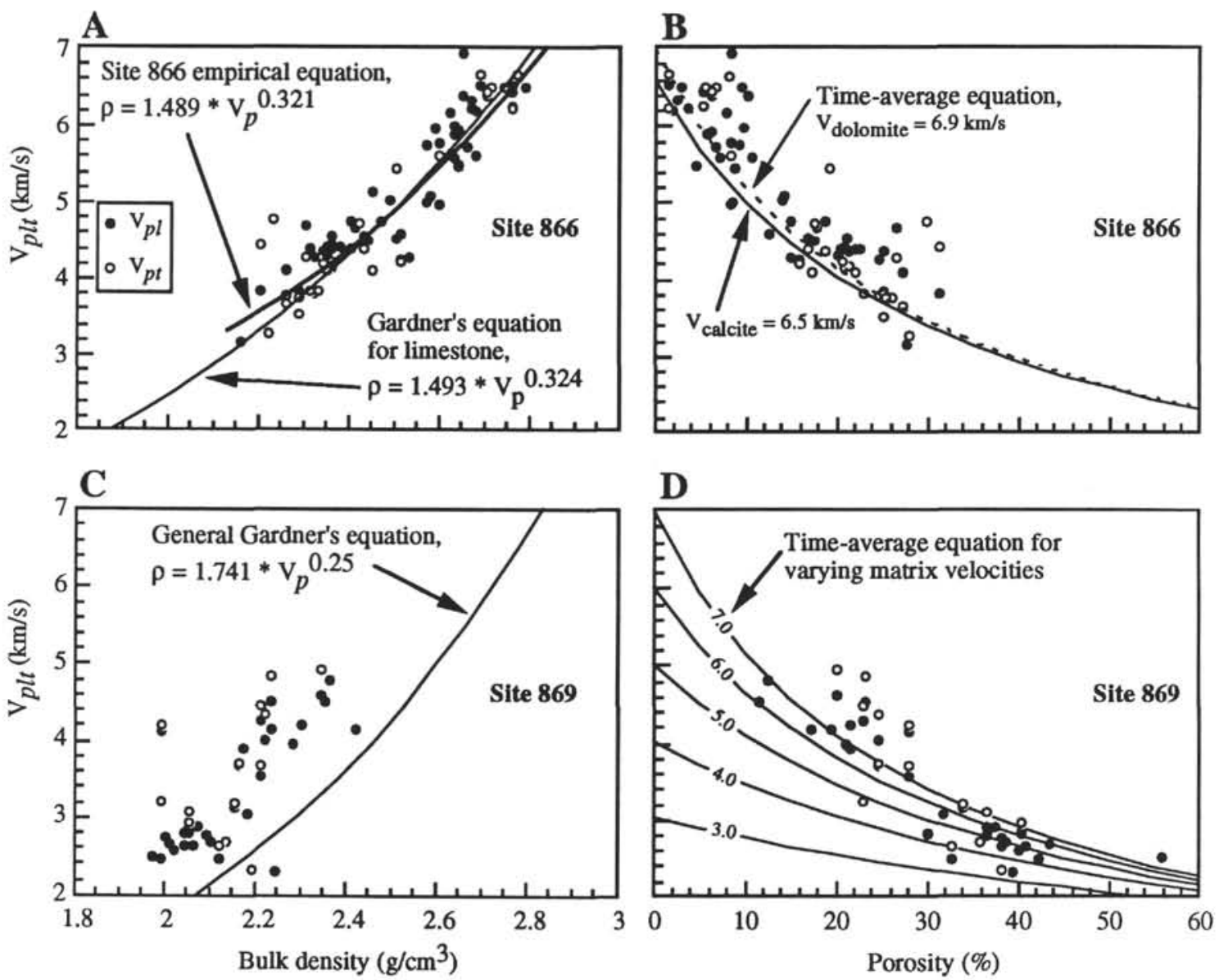

Figure 5. Crossplots between $V_{p t}$ measured under effective pressure vs. bulk density and porosity for both Site 866 (A and $\mathbf{B}$ ) and Site 869 (C and D). Gardner's equation is plotted along with bulk density- $V_{p l}$. Figure $5 \mathrm{C}$ shows curves representing the time-average equation at matrix velocities resembling those of the calcite and dolomite mineralogy, $V_{\text {calcite }}=6.5 \mathrm{~km} / \mathrm{s}$ and $V_{\text {dolomite }}=6.9 \mathrm{~km} / \mathrm{s}$. Similarly, Figure 5D curves represent the time-average equation at matrix velocities from 2.5 up to $8 \mathrm{~km} / \mathrm{s}$ at intervals of $0.5 \mathrm{~km} / \mathrm{s}$. See text for discussion. 

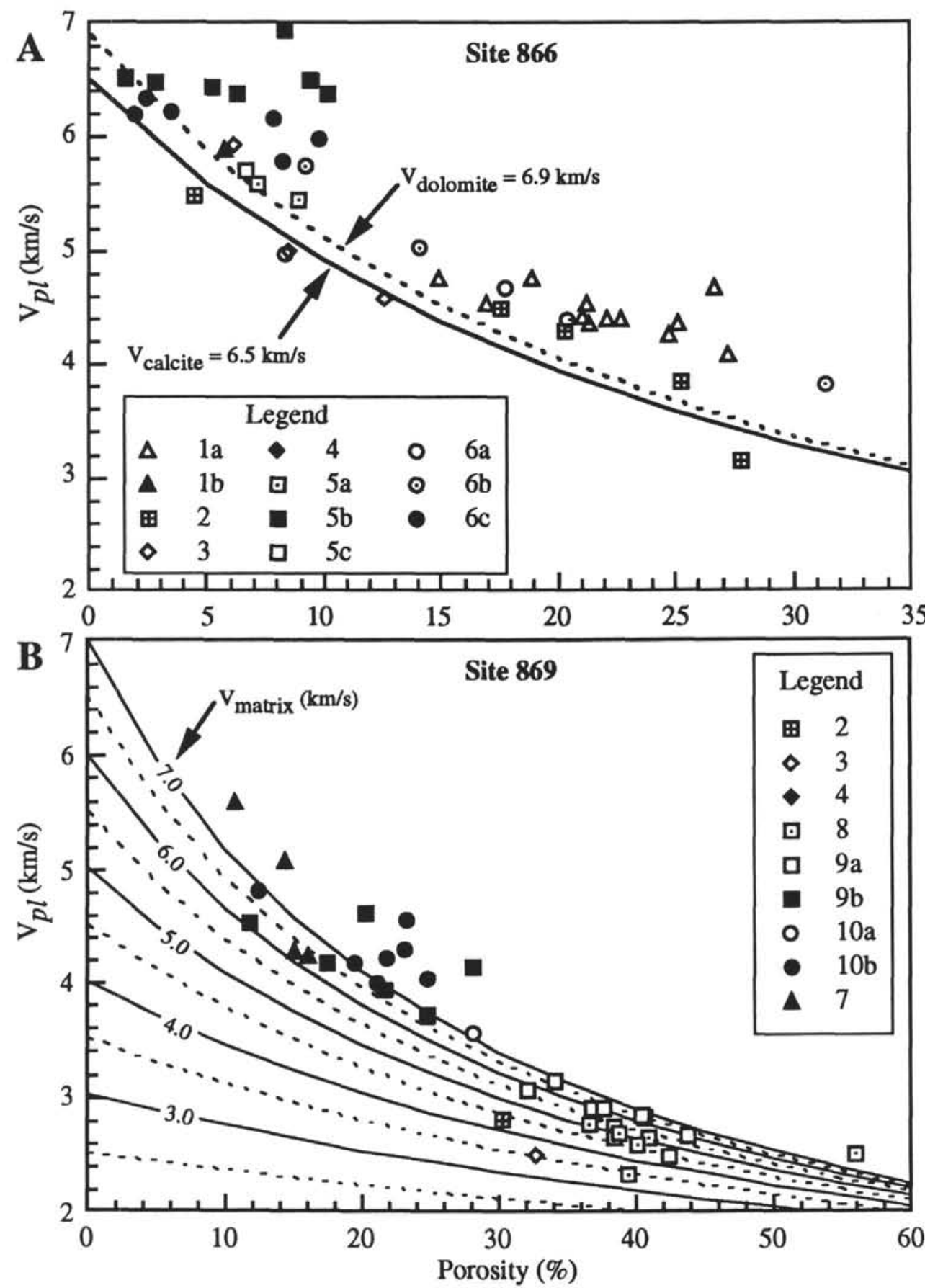

Figure 6. Crossplots of $V_{p l}$ measured under effective pressure vs. porosity for Site 866 (A) and Site 869 (B). Rock specimens are discriminated for petrographic character indicated by symbols (see Table 1 for explanation). See text for discussion.

basalt specimens from Site 866 were likely deposited subaerially, whereas the literature values are measurements of submarine basalt. The difference in the $V_{p l} / V_{s l}$ ratio and $P$-wave velocity may be explained by variations in the pore aspect ratios (Wilkens et al., 1991): low aspect ratios (i.e., cracks), corresponding to lower velocities and $V_{p l} / V_{s i}$ ratios and high velocities correspond to high aspect ratios (round pores). Minimal subaerial alteration of basalt may generate low aspect ratios (microcracks) that, without significantly changing the porosity, influence the velocity and $V_{p l} / V_{s l}$ ratio.

Similar to the porosity-velocity relationship in carbonates, more experimental data will be needed to resolve the precise relationship between $V_{p} / V_{p s}$ ratio, mineralogy, and the elongation of pores in basalts.

\section{Scaling}

Although some case studies that directly compare cross-hole seismic data and sonic velocity from wireline logs with discrete measurements of acoustic properties are highly successful (e.g., Sams et al., 1993), the correlation between log velocity and discrete velocity measured under effective pressure, $V_{p l}$, shows a relatively poor correlation for Site 866 . Log velocities between 3 and $5 \mathrm{~km} / \mathrm{s}$ have corresponding laboratory velocities of $5 \%$ to $15 \%$ higher. Log velocities of 5 to $7 \mathrm{~km} / \mathrm{s}$ have corresponding laboratory velocities that are significantly higher. Similar observations can be made from the correlation of $\log$ velocity with discrete velocity at Site 869 (Fig. 4B). 

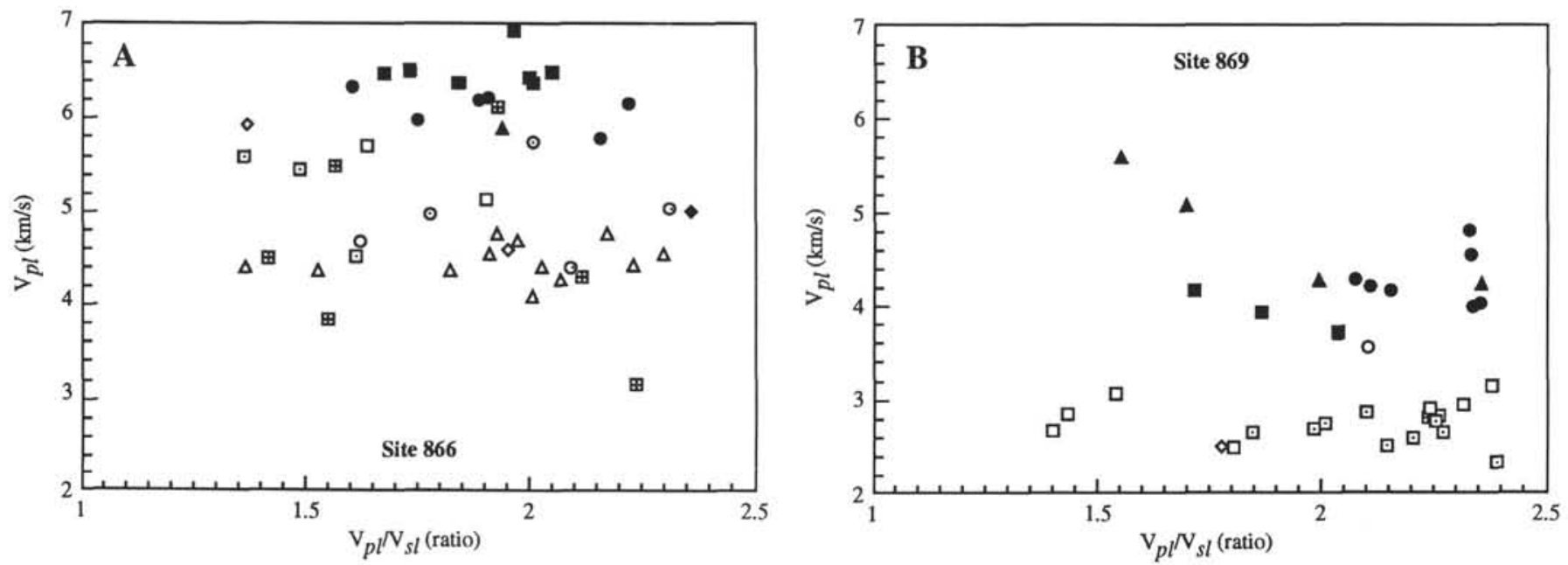

Figure 7. Crossplots of $V_{p l}$ measured under effective pressure vs. $V_{p l} / V_{s l}$ for Site $866(\mathbf{A})$ and Site 869 (B). Rock specimens are discriminated for petrographic character indicated by symbols (see Table 1 for explanation). See text for discussion.
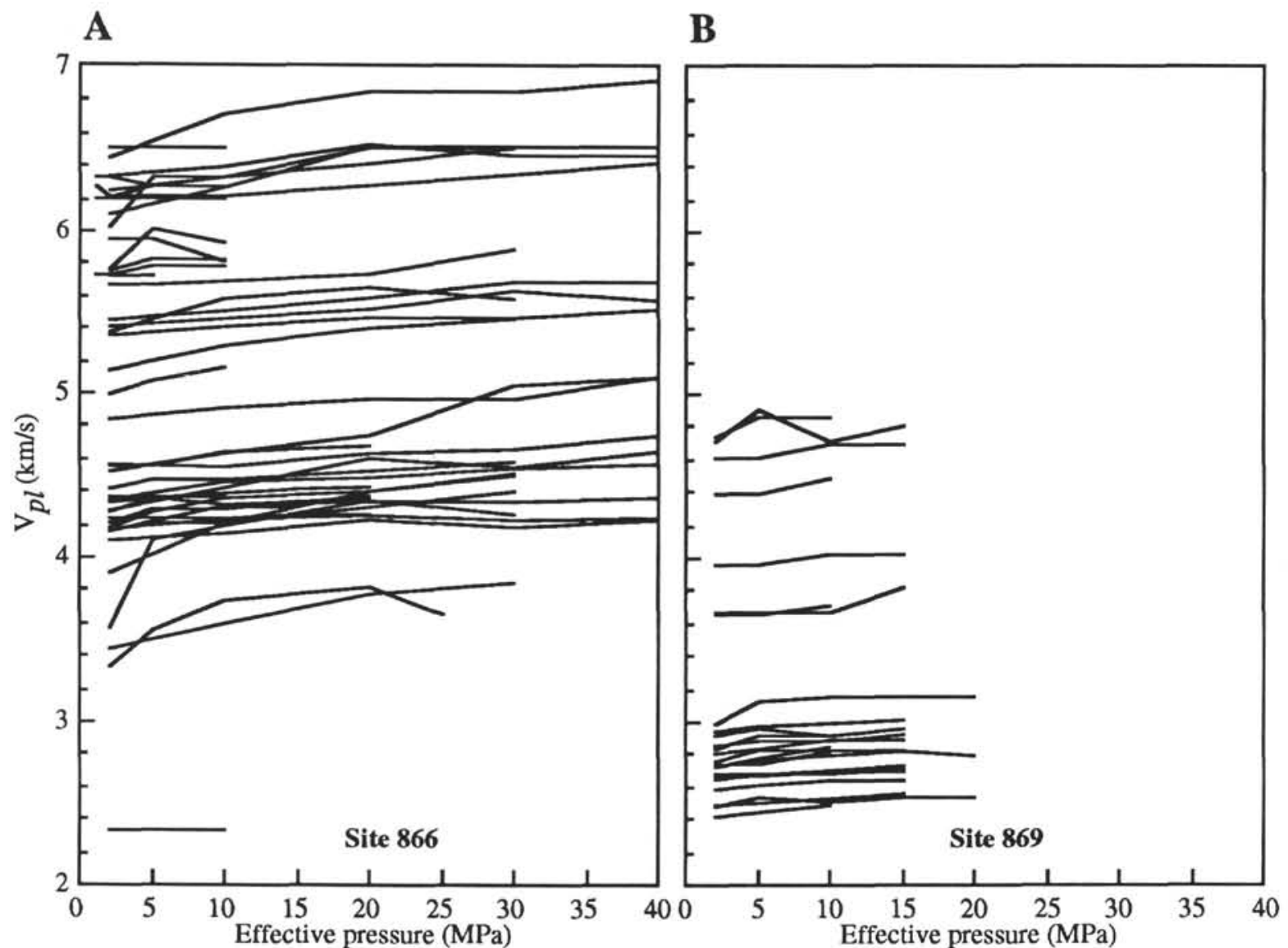

Figure 8. Crossplots of effective pressure vs. $V_{p l}$ for rock specimens from Site 866 (A) and Site 869 (B). See text for discussion 


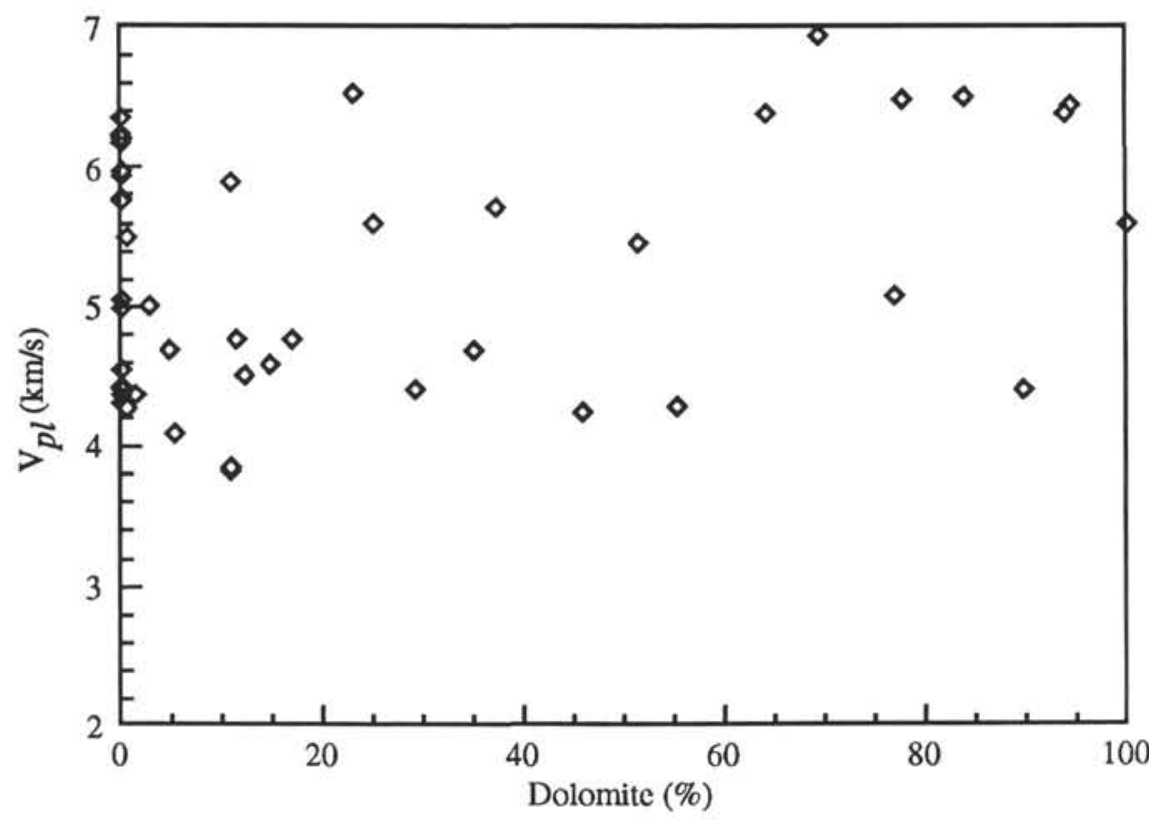

Figure 9. Crossplot of dolomite percentage and $V_{p l}$ for the carbonate specimens from Site 866 . Because rock specimens are nearly pure carbonates, the grain density is used to calculate the percentage of dolomite. See text for discussion.

Several factors influence the correlation of log velocity with discrete measurements of velocity. First, uncertainties exist in the depthmatching between sample location and position on the sonic log as a result of low recovery at both sites, $15 \%$ at Site 866 and $31 \%$ at Site 869 (Sager, Winterer, Firth, et al., 1993). Consequently, the progressive deviation of discrete velocity from log velocity toward higher values is probably related to the "selective" sampling of more competent (and therefore "faster") rock fabrics during coring operations (see Figs. $1 \mathrm{~A}$ and $\mathrm{IB}$ ). In addition, there is $\mathrm{a} \pm 2$ - $\mathrm{m}$ uncertainty between the methods used to calculate "log depth" and "core (pipe) depth." A second factor is the potential alteration of core samples during and after recovery, for example, because of desiccation or damage during trimming of the sample. Third, one of the most important effects is the introduction of velocity dispersion: seismic velocities increase with increasing frequency (Paillet and Cheng, 1991). Discrete measurements of velocity are performed using ultrasonic frequencies (1 $\mathrm{MHz}$ ), whereas the sonic $\log$ uses frequencies of $10 \mathrm{kHz}$. Fourth, the quality of the sonic log is closely related to the borehole's diameter and shape. Abundant cycle skipping in the sonic log raw data and poor hole quality (i.e., the presence of coring-induced fractures or other damage to the wall of the borehole; see caliper log, Sager, Winterer, Firth, et al., 1993) reduce the quality of the sonic log (Bourbie et al., 1987). In addition, the presence of a borehole forms a discontinuity in Earth's stress field and thus will influence the petrophysical properties of the surrounding rock. Fifth, the scale of lithologic, and therefore petrophysical, alternations within the core is critical compared to the sampling interval of the sonic log (scale of several meters).

Over the last few decades, thousands of measurements of sonic velocity have been performed under atmospheric and drained conditions on 1-in.-diameter cubes of lithified sediments using the Hamilton-Frame during ODP operations. The results of these analyses are available from the ODP data base, but are not calibrated to in-situ pressure conditions. As shown in Figures $3 \mathrm{~A}$ and $3 \mathrm{~B}$, a significant difference exists between measurements performed in the laboratory and in-situ conditions. Figure 9 demonstrates the increasing $P$-wave velocity measured on minicores, while increasing effective pressure to in-situ conditions. The difference between velocity measured at atmospheric and effective pressure mounts up to $25 \%$ for samples at Site 866. Several other factors are suggested to add to this discrepancy. First, ultrasonic analysis of centimetric samples requires precisely parallel sides to assure good coupling between the transducers and the rock specimens. Second, the distance between the transducers should be such that the emitted wave is virtually a plane wave on arrival (Bourbié et al., 1987). For 1-in.-diameter samples (cubes or minicores), the minimum length should be 1.5 in. (M.S. King, pers. comm., 1993). Neither of these two requirements is met by the 1-in. cube samples. More data will be needed to mathematically resolve the conversion of this vast ODP data set into values that reflect the in-situ conditions and to help in studying the calibration of discrete measurements of acoustic properties with wireline logs.

\section{SUMMARY AND CONCLUSIONS}

One hundred twenty-five 1-in.-diameter minicores from Sites 866 and 869 of Leg 143, consisting of carbonates and volcaniclastics, respectively, were analyzed for index properties (bulk density, grain density, and porosity) and acoustic properties ( $P$ - and $S$-wave velocities) under effective pressure with simulation of in-situ conditions (brine-saturated, drained). Petrographic analysis was used to classify fabric, primary texture, mineralogy, and pore type of each rock specimen. The acoustic properties were compared with shipboard measurements of adjacent 1-in.-diameter cubes and minicores under atmospheric pressure and also the sonic logs measured within the wells.

1. Diagenetic alteration of primary depositional texture is the predominant parameter that influences acoustic properties and porosity and, hence, the acoustic impedance of the carbonate specimens from Site 866.

2. Similarly, diagenesis is the controlling factor in the acoustic behavior of the volcaniclastic sediments of Site 869 .

3 . The time-average equation significantly underestimates the laboratory acoustic properties of the carbonates, whereas the Gard- 
ner's equation for limestone accurately describes the velocity-density relationship for the carbonates from Site 866.

4. Diagenetic alteration of the volcaniclastics is suggested to decrease the composite matrix velocity and to produce two discrete groups with discrete ranges in acoustic properties, but of similar genetic and compositional origin.

5 . The $V_{p l} / V_{s l}$ velocity ratio does not discriminate between dolomites and carbonates.

6. The limestones from Site 866 have a considerably wider range of impedance than the volcaniclastics from Site 869 and the basalt from Site 866. As a result, some lithologic boundaries may well be invisible in the seismic-reflection profiles.

\section{ACKNOWLEDGMENTS}

We wish to thank Captain Ed Oonk and the crew of the JOIDES Resolution, along with the ODP technical staff, for their support and cooperation during Leg 143. Use of the facilities of the Royal School of Mines, Imperial College, London, under the supervision of Michael King and with the assistance of Martijn Andrea and Mustafa Shams Khanshir, is greatly appreciated. We thank Marc Reinders for his assistance with laboratory analyses, and Jan Stafleu and Bruce Fouke for critically reviewing the manuscript. Will Sager, Rick Carlson, and Roy Wilkens are acknowledged for their helpful comments and suggestions. Funding to the first author was provided by Dutch National Science Foundation Grant No. 751.356.028 to Wolfgang Schlager.

\section{REFERENCES}

Anselmetti, F., and Eberli, G.P., 1994. Controls of sonic velocity in carbonates. Pure Appl. Geophys., 141 (2-4):287-323.

Bell, D.W., and Shirley, D.J., 1980. Temperature variation of the acoustical properties of laboratory sediments. J. Acoust. Soc. Am., 68:227-231.

Biddle, K.T., Schlager, W., Rudolph, K.W., and Bush, T.L., 1992. Seismic model of a progradational carbonate platform, Picco di Vallandro, the Dolomites, northern Italy. AAPG Bull., 76:14-30.

Birch, F., 1960. The velocity of compressional waves in rocks to 10 kilobars, 1. J. Geophys. Res., 65:1083-1102.

, 1961. The velocity of compressional waves in rocks to 10 kilobars, 2. J. Geophys. Res., 66:2199-2224.

Bourbié, T., Coussy, O., and Zinszner, B., 1987. Acoustics of Porous Media: Paris (Ed. Technip.).

Carmichael, R.S., 1989. Practical Handbook of Physical Properties of Rocks and Minerals: Boca Raton, FL (CRC Press).

Christensen, N.I., and Salisbury, M.H., 1975. Structure and constitution of the lower oceanic crust. Rev. Geophys. Space Phys., 13:57-86.

Dunham, R.J., 1962. Classification of carbonate rocks according to depositional texture. In Ham, W.E. (Ed.), Classification of Carbonate Rocks. AAPG Mem. 1:108-121.

Gardner, G.H.F., Gardner, L.W., and Gregory, A.R., 1974. Formation velocity and density: the diagnostic basics for stratigraphic traps. Geophysics, 39:770-780.

Gassmann, F., 1951. Elastic waves through a package of spheres. Geophysics, 16:673-685.

Gregory, A.R., 1977. Aspects of rock physics from laboratory and log data that are important to seismic interpretation. In Payton, C.E. (Ed.), Seismic Stratigraphy-Applications to Hydrocarbon Exploration. AAPG Mem. 26:15-46.

Hamilton, E.L., 1979. $V_{p} / V_{s}$ and Poisson's ratios in marine sediments and rocks. J. Acoust. Soc. Am., 66:1093-1101.

Han, D., Nur, A., and Morgan, D., 1986. Effects of porosity and clay content on wave velocities in sandstones. Geophysics, 51:2093-2107.

King, M.S., 1966. Wave velocities in rocks as a function of changes in overburden pressure and pore fluid saturations. Geophysics, 31:50-73.
King, M.S., Shams-Khanshir, M., and Worthington, M.H., 1993. Witchester seismic cross-hole test site: petrophysics studies of core. Int. Conf. Offshore Oil and Gas Field Prosp., Moscow. (Abstract)

Klimentos, T., and McCann, C., 1990. Relationships among compressional wave attenuation, porosity, clay content, and permeability in sandstones. Geophysics, 55:998-1014.

Kowallis, B., Jones, L.E., and Wang, H.F., 1984. Velocity-porosity-clay content: systematics of poorly consolidated sandstones. J. Geophys. Res., 89:10355-10364.

Kuster, G.T., and Toksöz, M.N., 1974. Velocity and attenuation of seismic waves in two-phase media: Part I-theoretical formulations. Geophysics, 39:587-606.

Nafe, J.E., and Drake, C.L., 1963. Physical properties of marine sediments. In Hill, M.N. (Ed.), The Sea (Vol. 3): The Earth Beneath the Sea [and] History: New York (Wiley-Interscience), 794-815.

Paillet, F.L., and Cheng, C.H., 1991. Acoustic Waves in Boreholes: Boca Raton, FL (CRC Press).

Rafavich, F., Kendall, C.H.St.C., and Todd, T.P., 1984. The relationship between acoustic properties and the petrographic character of carbonate rocks. Geophysics, 49:1622-1636.

Sager, W.W., Winterer, E.L., Firth, J.V., et al., 1993. Proc. ODP, Init. Repts., 143: College Station, TX (Ocean Drilling Program).

Sams, M.S., Worthington, H.M., King, M.S., and Shams Khanshir, M., 1993. A comparison of laboratory and field measurements of P-wave anisotropy. Geophys. Prospect., 41:189-206.

Spain, D.R., 1993. Petrophysical evaluation of a slope fan/basin-floor fan complex: Cherry Canyon Formation, Ward County, Texas. AAPG Bull., 76:805-827.

Stafleu, J., Everts, A.J.W., and Kenter, J.A.M., in press. Seismic models of a prograding carbonate platform: Vercors, SE France. Mar. Pet. Geol.

Tao, G., and King, M.S., 1990. Shear-wave velocity and Q anisotropy in rocks: a laboratory study, Int. J. Rock Mech. Min. Sci. Geomech., 27:353-371. (Abstract)

Tatham, R.H., 1982. $V_{p} / V_{s}$ and lithology. Geophysics, 47:336-344.

Tatham, R.H., and Stoffa, P.L., 1976. $V_{p} / V_{s}$-a potential hydrocarbon indicator. Geophysics, 41:837-849.

Toksöz, M.N., Cheng, C.H., and Timur, A., 1976. Velocities of seismic waves in porous rocks. Geophysics, 41:621-645.

Tosaya, C., and Nur, A., 1982. Effect of diagenesis and clays on compressional velocities in rocks. Geophys. Res. Lett., 9:5-8.

Vernik, L., and Nur, A., 1992. Petrophysical classification of siliciclastics for lithology and porosity prediction from seismic velocities. AAPG Bull., 76:1295-1309.

Wang, Z., Hirsche, W.K., and Sedgwick, G., 1991. Seismic velocities in carbonate rocks. J. Can. Pet. Technol., 30:111-122.

Wilkens, R.H., Fryer, G.J., and Karsten, J., 1991. Evolution of porosity and seismic structure of upper oceanic crust: importance of aspect ratios. $J$. Geophys. Res., 96:17891-17995.

Wilkens, R.H., Simmons, G., and Caruso, L., 1984. The ratio $V_{p} / V_{s}$ as a discriminant of composition for siliceous limestones. Geophysics, 49:1850-1860.

Winkler, K.W., 1983. Contact stiffness in granular porous materials: a comparison between theory and experiment. Geophys. Res. Lett., 10:10731076.

Wyllie, M.R.J., Gregory, A.R., and Gardner, G.H.F., 1958. An experimental investigation of factors affecting elastic wave velocities in porous media. Geophysics, 23:400.

Zenger, D.H., 1968. Determination of calcite and dolomite composition using the air comparison pycnometer. J. Sediment. Petrol., 38:373-377.

* Abbreviations for names of organizations and publications in ODP reference lists follow the style given in Chemical Abstracts Service Source Index (published by American Chemical Society).

Date of initial receipt: 29 November 1993

Date of acceptance: 13 June 1994

Ms 143SR-232 


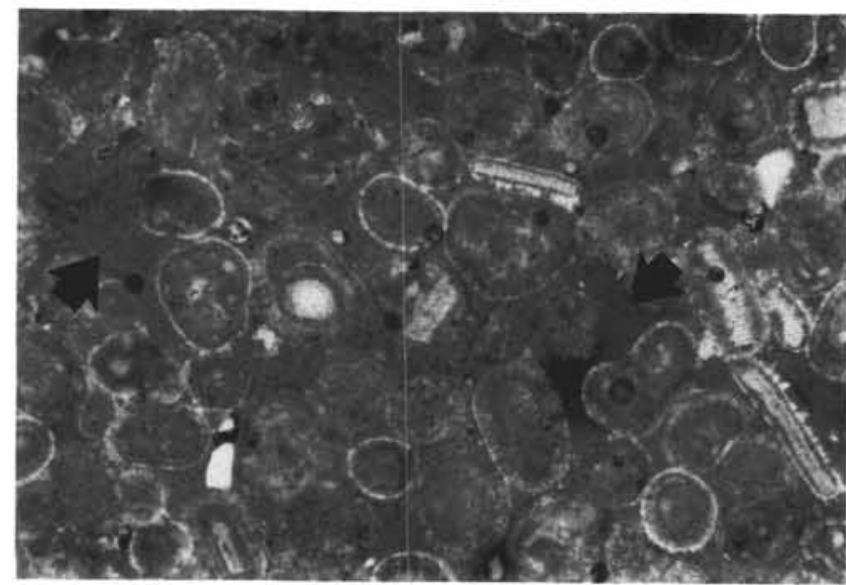

1

$1000 \mu \mathrm{m}$

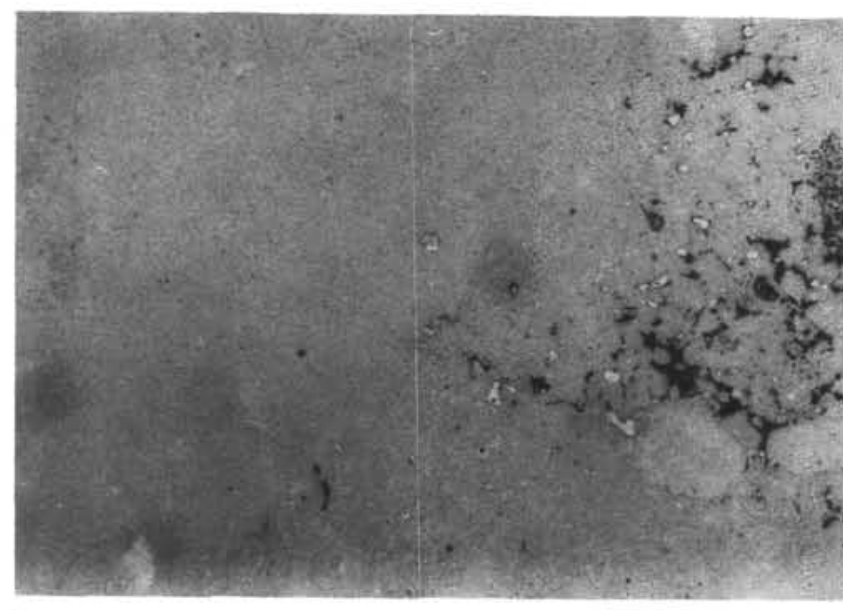

3

$2000 \mu \mathrm{m}$
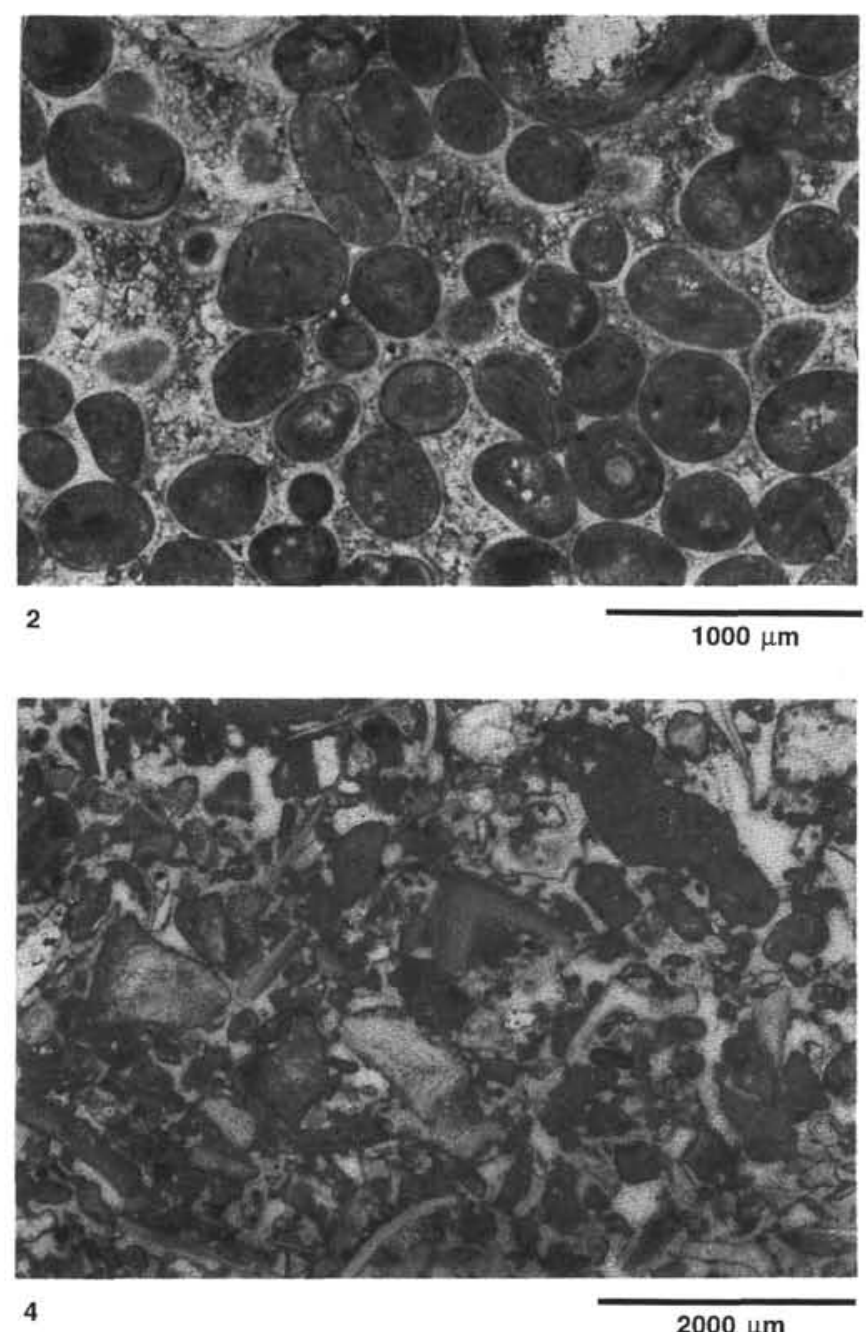

Plate 1. Photomicrographs of rock specimens illustrating typical petrophysical groups from Site 866 (see Table 1 for explanation). 1. Ooid grainstone with open interparticle porosity, Sample 143-866A-148R-1, 55-58 cm, Petrophysical Group la (arrow indicates porosity). Scale bar is $1000 \mu \mathrm{m} .2$. Ooid-skeletal grainstone with calcite cement filling interparticle porosity, Sample 143-866A-126R-1, 54-56 cm, Petrophysical Group 1b. Scale bar is $1000 \mu \mathrm{m}$. 3. Dense wackestone to mudstone, Sample 143-866A-31R-1, 120-122 cm, Petrophyscial Group 3. Scale bar is $2000 \mu \mathrm{m}$. 4. Dense, tight, skeletal rudstone with interparticle porosity filled by calcite cement, Sample 143-868A-5R-1, 75-77 cm, Petrophysical Group 6c. Scale bar is $2000 \mu \mathrm{m}$. 5. Dense, tight, skeletal rudstone with abundant moldic porosity (see arrow), Sample 143-867B-10R-1, 27-36 cm, Petrophysical Group 6cb. Scale bar is $2000 \mu \mathrm{m}$. 6. Skeletal rudstone with high interparticle porosity $(1 \%)$ and partial replacement by dolomite rhombs, Sample $143-866 \mathrm{~A}-156 \mathrm{R}-2,57-61 \mathrm{~cm}$, Petrophysical Group $6 \mathrm{a}$. Scale bar is $2500 \mu \mathrm{m}$. 7 . Skeletal grainstone with dolomite cement filling interparticle pore space and partially replacing components (see arrow), Sample 143-866A-124R-1, 30-33 cm, Petrophysical Group 5a. Scale bar is $500 \mu \mathrm{m}$. 8. Coarse crystalline dolomite with high (30\%) intercrystalline porosity (see arrow), Sample 143-866A-133R-2, $54-57 \mathrm{~cm}$, petrophysical group $5 \mathrm{~b}$. Scale bar is $3000 \mu \mathrm{m}$. 

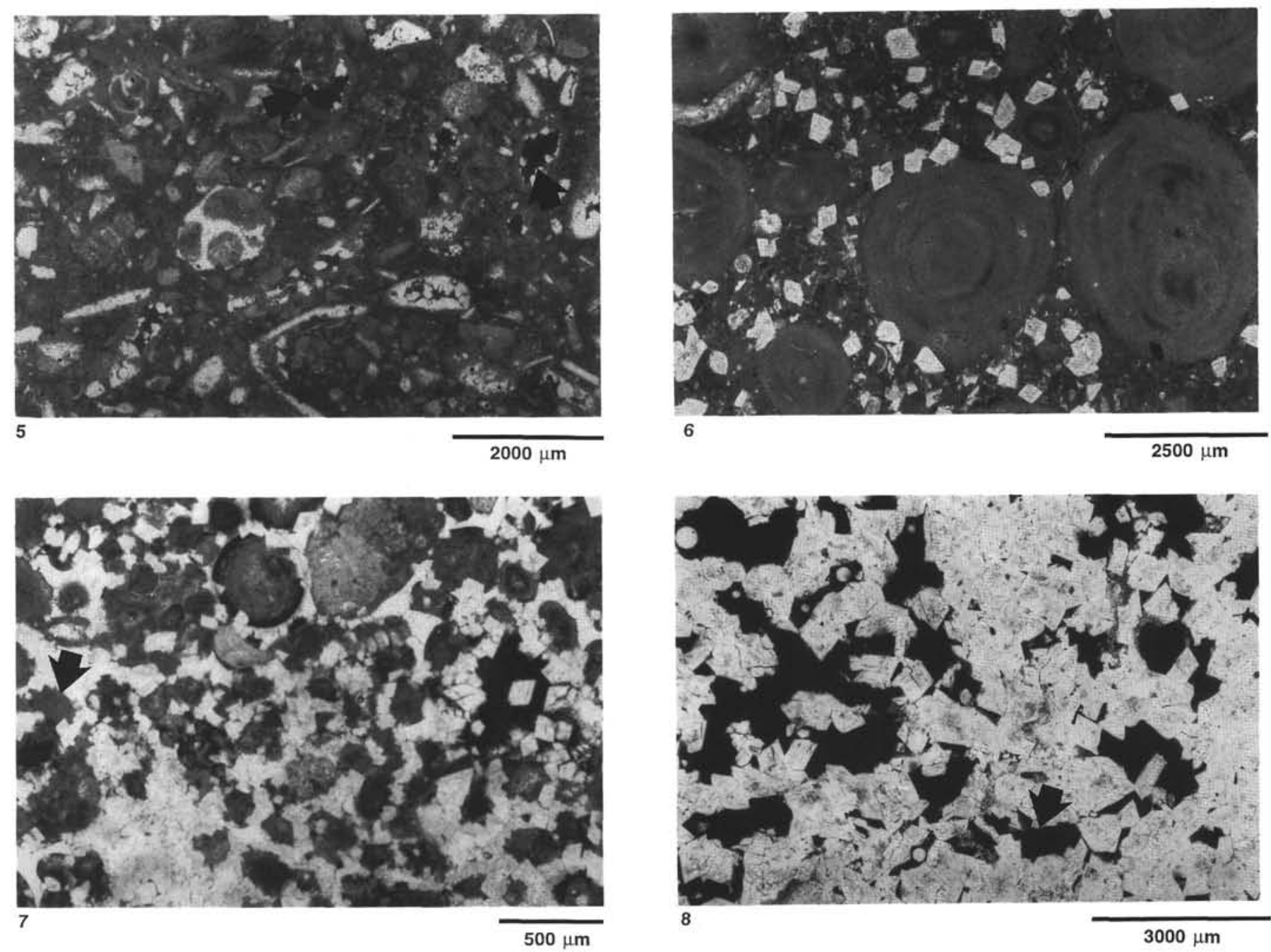

Plate 1 (continued). 


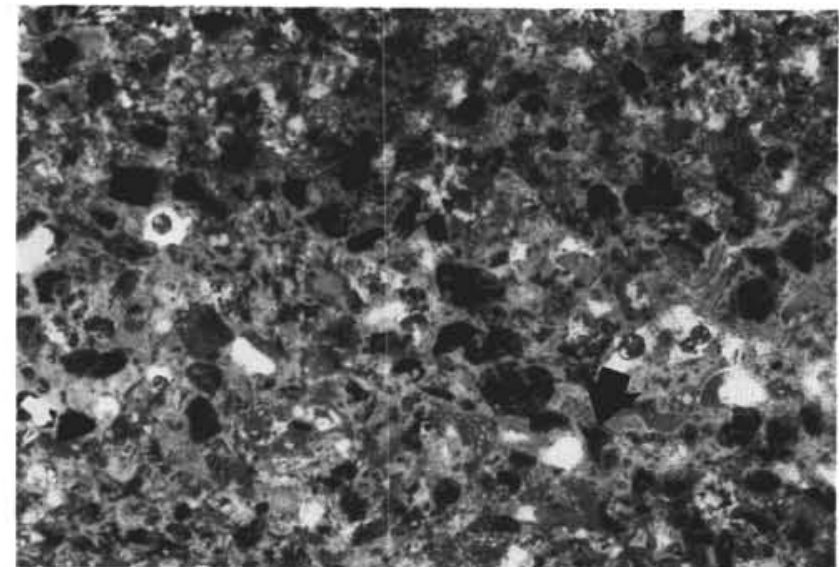

1

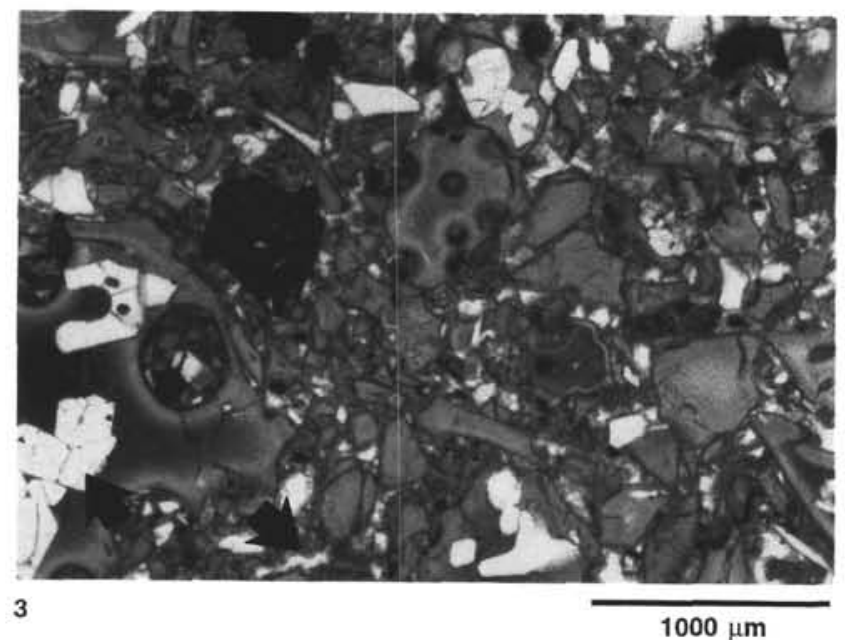

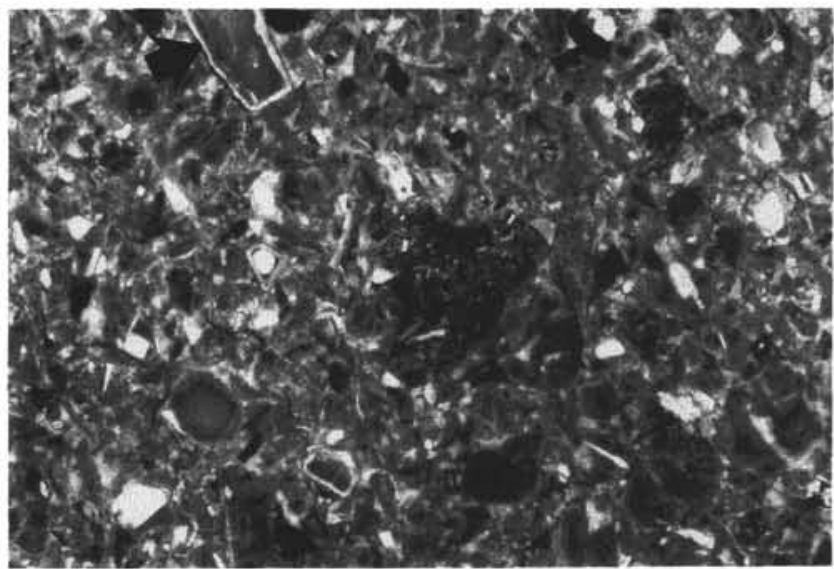

$1000 \mu \mathrm{m}$

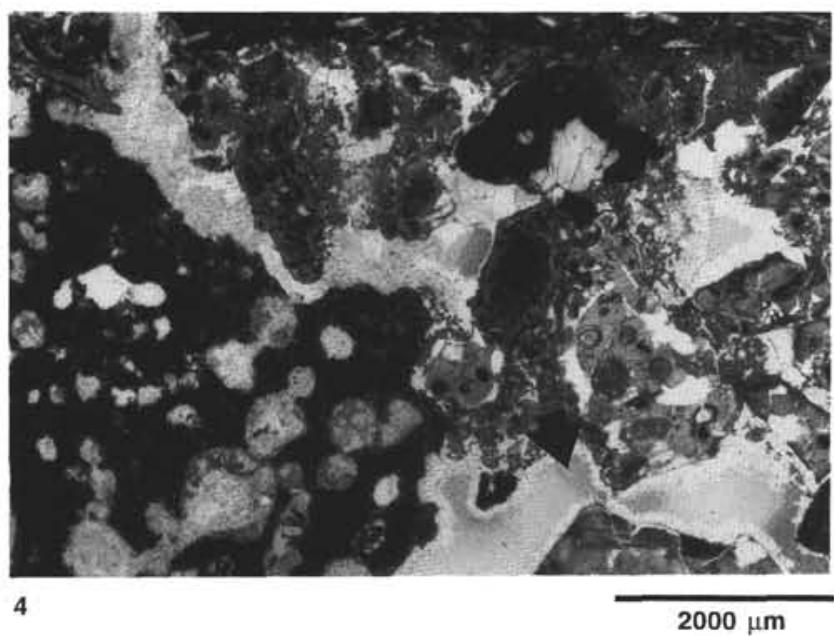

Plate 2. Photomicrographs of rock specimens documenting interesting characteristics of the petrophysical groups from Site 869 . 1. Volcaniclastic siltstone with highly altered grains, volcanic glass and basalt fragments with reaction rims (see arrow), Sample 143-869B-16R-1, $92-94 \mathrm{~cm}$, Petrophysical Group 8. Scale bar is $500 \mu \mathrm{m}$. 2. Volcaniclastic sandstone with highly altered grains, volcanic glass and basalt fragments with reaction rims (see arrow), Sample 143-869B-61R-1, $37-44 \mathrm{~cm}$, Petrophysical Group 9a. Scale bar is $1000 \mu \mathrm{m}$. 3. Volcaniclastic sandstone with unaltered grains and zeolite replacing components and filling interparticle pore space (see arrows), Sample 143-869B-61R-2,41-48 cm. Petrophysical Group 9b. Scale bar is $1000 \mu \mathrm{m}$. 4. Volcaniclastic breccia with unaltered grains and zeolite replacing components and filling interparticle pore space (see arrow), Sample 143-869B-54R-1, 93-99 cm, Petrophysical Group 10b. Scale bar is $2000 \mu \mathrm{m}$. 